\title{
Распутинская сенсация на страницах российской прессы. Становление аналитического, оппозиционного и «желтого» направлений освещения темы. Май-июнь 1910 г.
}

\begin{abstract}
Аннотаиия. Предлагаемая статья посвящена исследованию малоизученных аспектов становления и развития медийного мифа о Григории Распутине, ставшего в начале ХХ в. одной из важнейших предпосълок общеполитического кризиса накануне Февральской революиии 1917 г. Авторы подробно проанализировали прочесс публичистической диверсификаиии распутинской темы на странииах российских газет, который привел к появлению трех основных журналистских подходов к этой теме: беспристрастно-аналитического, либерально-оппозииионного и «желтого» (бульварного). Каждый из этих подходов подвергнут всестороннему рассмотрению, включая сравнительный анализ с подходами иного типа. В статъе отмечена роль как общественно-политической, так и коммерческой мотивачии в освещении газетчиками распутинской темы. Выявлены различные иели, которые преследовали журналисты и СМИ, развивавшие соответственно каждое из трех направлений. Аналитическое направление характеризовал интерес к Распутину как к личности, а также профессиональнвии подход к фактам, которые не публиковались без ссылок на источник и строго отделялись от комментария. Целью оппозичионных публикачий, посвященных “стариу», была максимальная дискредитачия его, а через него и всего правящего режима. “Желтый» подход стремился лишь к «нагнетанию страстей» и был лишен аналитической составляющей, делая главный акчент на эротических подробностях слухов о Распутине.
\end{abstract}

Ключевые слова: Распутин, «стареч», журналистика, газеты, «желтая пресса», эксклюзивный материал, либеральная оппозииия, кадетьи, крайне правые, хльсты.

Abstract. This article is devoted to the research of the little-studied aspects of the formation and evolution of Rasputin's media myth, which at the beginning of the 20th century became one of the most important factors in the general political crisis on the eve of the February Revolution of 1917. The authors analyse in detail the process of the publicist diversification regarding the topic of Rasputin on the pages of Russian newspapers that lead to the appearance of three main journalistic approaches to this topic: impartial-analytical, liberal-oppositional, and "yellow" (tabloid). Each of these approaches is subjected to a comprehensive review, including a comparative analysis with other types of approaches. The article notes the role socio-political, as well as journalists' commercial motivation in presenting the Rasputin question. The authors identify the different aims that journalists and the media pursued, which developed each of the three approaches respectively. The analytical direction was characterised by its interest in Rasputin as a separate figure, as well as a professional approach to facts, which were published with references to their sources and were strictly separated from personal commentaries. The aim of oppositional publications, devoted to "the elder", was his ultimate discrediting and, through him, of the whole ruling regime. The "yellow" approach sought only to "escalate passions" and was deprived of an analytical component, placing its main emphasis on rumours of erotic nature about Rasputin.

Key words: liberal opposition, exclusive material, "yellow press", newspapers, journalism, "elder”, Rasputin, cadets, far right, Khlysts.

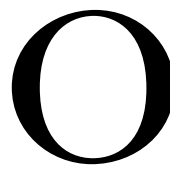

бсуждение личности скандального царского фаворита Григория Распутина явилось одной из наиболее резонансных сквозных тем российской журналистики межреволюционного периода.
При этом, помимо общественно-политического, распутинские сенсации имели для периодических изданий вполне прагматический экономический смысл, так как повышали популярность газет и косвенно влияли на их тиражность. По- 


\section{Исторические факты, события, феномены}

этому неудивительно, что первой общероссийской газетой, которая включилась в обсуждение распутинской темы, явилось «Русское слово»самое тиражное издание дореволюционной России. «Русское слово» выходило в Москве, в 1914 г. его тираж превышал 500 тыс. экз. [1].

На июнь 1910 г. газетная популярность Григория Распутина достигла своего рода апогея. Сенсация развивалась более полугода. Распутин стал героем всероссийской прессы на рубеже 1909-1910 гг. в связи с протекцией, которую он оказал царицынскому иеромонаху Илиодору [2; $3 ; 4 ; 5]$.

Затем, после небольшого перерыва, он вернулся на полосы повременных изданий уже как герой скандальных публикаций $[6 ; 7 ; 8 ; 9 ; 10 ; 11$; $12 ; 13 ; 14 ; 15 ; 16]$.

В конце весны - начале лета 1910 г. некоторые газетные редакции командировали репортеров на родину «старца», поручив им лично встретиться с ним и затем отразить свои впечатления в публикации. В связи с этим обращают на себя внимание три наиболее масштабных эксклюзивных материала А. Сенина, опубликованных в екатеринославской газете «Южная заря», а также статьи, напечатанные в двух екатеринбургских изданиях - «Уральском крае» и «Уральской жизни».

При этом, в отличие от Сенина, который исследовал жизнь и личность Распутина, «стараясь быть при этом вполне объективным» [17], екатеринбургские газеты, изначально шедшие в информационном фарватере кадетского официоза «Речи» и перепечатывавшие публиковавшиеся в ней «антираспутинские» материалы, преследовали иные цели $[18 ; 19 ; 20 ; 21 ; 22 ; 23 ; 24]$.

К. Жданов, корреспондент «Уральского края» (издания, контролировавшегося екатеринбургским комитетом партии кадетов [25]), действовал в русле уже успевшего обозначиться на страницах «Речи» курса на использование распутинского сюжета как инструмента оппозиционной пропаганды. И потому вне зависимости от того, какие новые сведения об этом человеке оказывались в его распоряжении, свою первоначальную - априорно негативную оценку Распутина как “"старца” сомнительной старости», «пресловутого подвижника», «мазурика», «“блаженного” святоши» [26], «юродивого распутника» [27] и т. д. Жданов не корректировал. Его мнение о Распутине оставалось критически однобоким как до знакомства с ним, так и после.
DOI: $10.7256 / 2222-1972.2015 .4 .17043$

«Газета общественная, литературная и экономическая», как она сама себя обозначала, «Уральская жизнь» в основном специализировалась на «желтых» сюжетах - громких светских и церковных скандалах. Поэтому Григорий Распутин интересовал ее корреспондента, подписывавшегося псевдонимом «Володюша» (Швейцер Владимир Захарович [28, 161]), именно как скандальная «звезда» всероссийского масштаба. Цель журналистского расследования автора «Уральской жизни» ни в коем случае не заключалась ни во всестороннем рассмотрении человеческих качеств Распутина, ни в попытке проанализировать его судьбу. Вместо этого журналист стремился к обнародованию максимального количества «жареных» новостей о популярном персонаже.

Особенности трех публицистических подходов - аналитического, оппозиционного и «желтого» - с наибольшей наглядностью проявились в ходе описания журналистами их личных встреч и бесед с героем их публикаций. Но прежде чем перейти к анализу этих описаний, необходимо проследить, как именно каждый из репортеров готовился к встрече со «старцем», какую именно информацию собирал и как ее затем упоминал и комментировал в текстах публикаций.

А. Сенин помимо тех - в основном точных биографических данных о Распутине, которые он сообщил в майском номере «Южной зари», в июньских частях своего распутинского цикла поведал об особенностях отношений Григория с односельчанами и о его попытках наладить общение с местным духовенством.

«Приезжал потом (в 1907 г. - Д. К., Е. С.) Григорий Новый (Распутин) на Пасху и привез 5 тысяч на новую церковь в с. Покровском. Собрали сход и предложили приходу принять на себя какую-либо долю участия в расходах по постройке нового храма. Сход наотрез отказался и денег не принял. “Знаем мы эти 5 тысяч... только согласие-то дай, а уж там не отвертишься... Хочешь строить - строй... Вот тебе место и... больше ничего...", - решили старики. Очень это огорчило Распутина. Злые языки уверяли, что он пожертвование свое привез с задней мыслью подкупить этим расположение к себе тобольского епископа, который относился к нему весьма недоброжелательно и, несмотря на неоднократные и настойчивые попытки и содействие друзей своих, ни разу не был допущен к приему преосвященного. Несколько раз ездил Григорий 


\section{Исторический журнал: научные исследования № 4 (28) • 2015}

DOI: 10.7256/2222-1972.2015.4.17043

в Тобольскую (консисторию. - Д. К., Е. С.) с целью представиться архиерею, и каждый раз безуспешно. Дело в том что, как мне удалось слышать от одного священника, тобольский епископ подозревает в нем сектанта» [29].

Не ссылаясь на конкретный источник, но и не давая личных оценок, Сенин кратко пересказывает суть упомянутого «сектанства», в котором подозревался Распутин:

«По сведениям, имеющимся у епископа, учение этой “новой секты” заключается приблизительно в следующем: церковь утеряла ту чистоту, которую она имела во времена апостольские; священство не на высоте своего призвания; многие представители духовенства недостойны, чтобы благодать Святого духа пребывала в них, а потому часть благодати, отпущенной на них, остается свободною; эта “свободная" благодать и может снизойти на достойнейшего из непосвященных в духовный сан.

Посредством истовой и продолжительной молитвы “наставник" приходит в религиозный экстаз и начинает прорицать, исцелять, давать советы.

Но хотя церковь и потеряла свою чистоту и спастись через нее нельзя, но, принимая во внимание, что полный разрыв с нею и открытое исповедание новой веры может навлечь много неприятностей, положено внешним образом исполнять все православные обряды» [29].

Сенин попытался лично разобраться в вопросе о предполагаемом сектантстве Григория Распутина и описал в связи с этим два эпизода.

В первом из них в роли источника информации выступил еще один политический ссыльный - социалист Григорий Зайцев, оказавшийся проездом в Покровском:

«Раз мелькнула было у меня надежда выяснить истинную природу Григория. Летом 1907 г. проходил этапом каторжанин Григорий Зайцев, политический. Родом он из Петербурга, 20 июня в почтово-телеграфном отделении с. Покровского был получен денежный перевод на имя Зайцева из Тобольска от г-жи К. и письмо, что адресат будет на днях в Покровском. Г-жа К., по словам Зайцева, высоконравственная личность и вместе со своими дочерьми занимается благотворительностью в тобольских тюрьмах. По своим политическим воззрениям она стоит вне партий; ее единственная цель - благотворительность... Я рассказал Зайцеву о нашем "святом". Оказывается, он тоже слышал о нем, а с Берладской Хионией, которая гостит у Григо- рия, знаком даже. По словам Зайцева, “секта”, к которой принадлежит и г-жа К., и Григорий, ставит своей целью нравственное совершенствование. Между “братьями” и “сестрами”, по его мнению, существуют чисто братские отношения. В тот же день Зайцев имел свидание с Григорием и Берладской. Тем же летом приезжала г-жа К. к Григорию Новому с своими дочерьми, но скоро уехала обратно, так как ей что-то не понравилось в Распутине. Все это - и отзывы Зайцева, и визит г-жи К. вконец спутали меня, и личность Григория Распутина казалась мне еще более загадочной, необъяснимой» [29].

Второй эпизод был связан с расследованием, организованным местными церковниками в отношении Распутина, и содержал ценные свидетельства очевидцев:

«Между тем, местное духовенство усиленно следило за Распутиным и его учениками. Настоятель Покровской церкви о. Остроумов потребовал от Григория, чтобы тот не являлся на клирос в своем золотом кресте (судя по всему, имелся в виду крест, подаренный Распутину Николаем II. Д. К., Е. С.). Григорий повиновался. Тем же настоятелем было предложено Илье Арапову либо отказаться от Григория, либо от церкви. Илья пообещал прервать связь с Григорием, но обещания своего не исполнил.

К 1 января 1908 г. Григорий снова появился в с. Покровском с целой свитой: г-жа Л. (Лохтина О. В. - Д. К., Е. С.), г-жа Б. (Берладская Х. М. Д. K., E. C.) с мальчиком, какая-то купеческая дочка, курсистка, сестра милосердия (Лаптинская А. Н. - Д. К., Е. С.). "На Григория" у Распутина был устроен праздник. Пригласил Григорий всех местных именитых людей и батюшек. "Не откажите удостоить посещением своим убогую келию мою. Смиренный раб Григорий”, - писал, между прочим, Григорий священникам в своих пригласительных записках. Получил в тот день Григорий поздравительные телеграммы от многих своих высоких покровителей.

Но в ту же ночь и большая неприятность случилась с Распутиным и его гостями. Ночью произведен был у него допрос и обыск. Тюменский миссионер Глуховцев в сопровождении настоятеля Покровской церкви Петра Остроумова и другого священника Федора Чемагина обыскали весь дом, баню, амбары, подполье и все закоулки, ища кадку, вокруг которой происходили будто бы радения. Ничего найдено не было. Все гости были подробно расспрошены: имя, отчество, фамилия, место жительства, зачем при- 


\section{Исторические факты, события, феномены}

DOI: $10.7256 / 2222-1972.2015 .4 .17043$

ехали. На последний вопрос был единогласный ответ: в гости.

Самому Распутину был предложен довольно щекотливый вопрос: правда ли, что он ходит в баню с “сестрами”.

Григорий отвечал отрицательно.

Тогда свящ. Федор Чемагин сказал: “Зачем же ты врешь, Григорий, я сам видел это: помнишь, летом, когда я пришел к тебе однажды, ты возвратился из бани с веником, а вслед за тобою из бани же гости твои, дамы”.

- Так что ж? - отвечал Григорий, - Я только в предбаннике лежал.

- А правда ли, - спрашивает миссионер, свидетельница просфорня Авдотья К. показывает, что года три тому назад, когда она возвращалась с богомолья, ты зазвал ее к себе, начал целовать, а потом сделал ей гнусное предложение и даже посягнул на оное действием? Когда же она стала оказывать сопротивление и называть тебя бесстыдником, ты сказал ей: "Никакого греха со мной нет”, - и потом еще о благодати начал говорить?

Григорий отвечал отрицательно.

(Подробности обыска и допроса передаю со слов свящ. Петра Остроумова.)

Сделав обыск и допрос, Глуховцев извинился и, уезжая, приглашал Григория с гостями на чашку чая» [29].

Помимо указанных двух эпизодов, оставивших вопрос о т. н. сектантстве Григория Распутина открытым, А. Сенин также упоминает о слухах, постепенно сгущавшихся вокруг «старца», окруженного столь пристальным вниманием со стороны церковных функционеров:

«Несмотря на все внешние приличия Григория Распутина и его последователей, темные слухи все росли и росли. Многие уверяли, что видели Григория, как он целовался и творил грех с “сестрами” в лесу, другие говорили, что по ночам у них происходят радения, что Григорий ходит с “сестрами” в баню, где поочередно заставляет их мыть себя, что будто бы жена его ревнует Григория к “сестрам" и раз даже бегала за г-жой Б. с топором по двору» [29].

Корреспондент «Уральского края» К. Жданов так же, как и А. Сенин, предпринимает попытку составить биографию «старца». Но, в отличие от Сенина, делает ставку исключительно на порочащие Распутина и его близких рассказы. При этом исходят они в основном от анонимных повествователей, чья прямая речь весьма напоминает не слишком изящную беллетристическую имитацию «народной стилистики»:

«Распутины - фамилия одних из тех крестьян, которые были основателями села Покровского. Любопытно, между прочим, отметить несколько легендарное объяснение, упрочившееся среди крестьянства, тому, как произошла эта фамилия:

- Предки-то нашего “святого” Григория-то, значит, вот не лучше его самого были. Пьянствовали. Дебоширили завсегда, до женщин падки очень были. Одно слово, распутничали... Распутины раньше Распоповы были, да только как конфуз этот вышел, сродственники первые на сходе, говорят, за то кричали, чтобы и из общества исключить, и фамиль перекрестить» [30].

Дает Жданов - опять-таки без ссылки на источник - и новое объяснение легендарного прозвища Григория «вытул» (нар. - выскочка, эксцентрик) - также уничижительное и оскорбительное, притом по отношению ко всему семейству Распутиных:

«Еще только что родившемуся хилому ребёнку к имени Григорий злыми языками было прибавлено прозвище "Вытул”. "Гришка Вытул”. Так был назван ныне “экс-блаженный старец” Григорий Распутин, будучи в колыбели, по следующему поводу.

Отец Григория Ефим Яковлевич Распутин, будучи очень развратным сластолюбцем, не оставлял своей жены своими приставаниями даже во время беременности. То же было, когда жена забеременела будущим “старцем” Григорием.

На протесты слабой женщины старый похотливец обычно кричал:

- Вытуляй его (ребёнка) скорее, вытуляй!

Очень долго в селе знали только "Гришку Вытула”.

Гришкой был и малолетний ребёнок, и школьник - кстати сказать, до поразительности неспособный, отличающийся тупоголовием (Григорий Распутин учился довольно долго в сельской церковно-приходской школе, но так и вышел, измучившись, но не научившись ни читать, ни писать как следует. Позднее, уже за последние 4 года, он, “гастролируя” по салонам, несколько сноснее стал знать грамоту, а то не без труда писал даже свою фамилию...), - и рано начавший развратничать юнец, и восемнадцатилетний юноша, вступивший в законный брак, и освободившийся как единственный в семье сын от отбывания воинской повинности совершен- 


\section{Исторический журнал: научные исследования № 4 (28) • 2015}

\section{DOI: $10.7256 / 2222-1972.2015 .4 .17043$}

нолетний молодой человек, и после этого в течение, по крайней мере, десяти еще лет имеющий по селу неважную репутацию и славившийся пьяным разгулом “Вытул”... Но, достигнув тридцатилетнего возраста, "Гришка Вытул” образумился и с дороги пьянства и дебоша круто повернул в сторону религиозного ханжества. Тут он только является не “Вытулом", а Григорием Распутиным» [31].

Рассказывая историю духовного перевоплощения Распутина, Жданов старается ввести в нее побольше деталей, компрометирующих прошлое и настоящее «старца»:

«Распутин, обнаруживая достаточно сильную волю, действительно почти мгновенно бросает пить вино, бросает пьяный разгул, бросает курить табак, несмотря на то что до того времени он курил очень много, и даже при посредстве какой-то особенно больших размеров трубки. Единственно, что не бросает он, - это половой разврат, - ему он остается верен, будучи и ханжей-святошей, и “подвижником”... Половая разнузданность не только не уменьшается, а наоборот развивается все более и более, быстрее даже, чем его “подвижническая популярность”... И “святоша-Вытул” идет паломничать по святым местам...

Позднее приобрел уже славу “святого”, у него появились “братчики-старцы” и другие последователи, сообща с которыми он устраивал "молитвенные собрания", когда жил в старом доме, местом для этого собрания служила конюшня, а по переезде в новый дом - непосредственно в доме. Что это за "молитвенные собрания” были, точно установить пока не удается, но очень хорошо известно, что эти же собрания устраивались и в бане, где все присутствующие представали друг перед другом нагими, не исключая и женщин... Из последних обыкновенно всегда находились вместе с Григорием "блаженным” две его “духовные сестры” (тетка с племянницей, из Абалака), пристав к нему еще в первые годы его “подвижничества". Когда же он начал “гастролировать”, то в период его проживания на родине к нему являлись “столичные” гости, также участвовавшие в “собраниях" в бане. Преимущественно это были дамы, а чаще всех генеральша Лохтина... Известно даже, как "Богородица-генеральша” (Лохтина. - Д. К., Е. С.) провозгласила его, этого проходимца Распутина, Иисусом Христом» [31]. (В действительности О. В. Лохтина, судя по всему, страдавшая прогрессирующим бредовым расстройством, назы- вала «Иисусом Христом» иеромонаха Илиодора, а Григория Распутина - «Саваофом» [20, 267].)

Ссылаясь на слова П. Остроумова, с которым Распутин, несмотря на предыдущие принципиальные разногласия и публичные ссоры, теперь якобы откровенничает, Жданов приводит весьма неоднозначную информацию: «Опальный “экс-блаженный старец” Распутин в одной из своих недавних бесед со священником церкви села Покровского, о. Петром Остроумовым, очевидно, в порыве большого откровения, чистосердечно сознался, что утратил свое значение (он выразился даже - “влияние") в высших сферах лишь потому, что лица, протежировавшие ему во всем, были вытеснены из среды камарильи. С этого момента и началось его падение, а вместе с тем от него, как это бывает с дутыми “авторитетами”, сразу отшатнулись и его поклонники. Остались лишь немногие фанатичные последователи (тоже “старцы”), да психопатки-поклонницы...» [31]. Заявление о том, что поклонницы «старца»- «психопатки», звучало весьма резко, учитывая, что еще летом 1909 г. императрица Александра Федоровна прилюдно поцеловала Распутину руку на одной из церковных служб [32, 172]. Взяв, таким образом, высокую оппозиционную ноту, кадетский публицист продолжал: «Его (Распутина. - Д. К., Е. С.) “религиозный” разврат, его половая разнузданность, преподнесенные под соусом какой-то туманной теории “о спасении души путем плотских сношений”, - пришлись по сердцу и вкусу столичных психопатов и психопаток... Однажды (в 1906 г.) благодаря своим “влиятельным” поклонницам и поклонникам Распутин имел случай преподнести складную икону одному из высокопоставленных лиц. С этим временем как раз совпало первое неудавшееся покушение на это лицо. Оправившись от испуга, сановник высказал убеждение, что он спасся, благодаря иконе, преподнесенной ему Распутиным...» [33]. В данном случае, как нетрудно понять, имел место весьма приблизительный (как большая часть сообщаемых Ждановым фактов) пересказ истории посещения Распутиным раненой дочери премьер-министра П. А. Столыпина.

В отличие от Сенина, уклонившегося от того, чтобы высказать свою точку зрения на фактологически не проясненную проблему распутинского «сектантства», либерал Жданов, по сути, солидаризируется с соответствующими обвинениями, которые предъявил Распутину крайне правый епископ Феофан: «Преосвящен- 


\section{Исторические факты, события, феномены}

DOI: $10.7256 / 2222-1972.2015 .4 .17043$

ный отец Феофан (ректор С.-Петербургской духовной академии), который, вовремя отшатнувшись от Григория “блаженного”, обращаясь за последние месяцы к священнику села Покровского, о. Петру Остроумову с предложением - "неустанно следить за преступным пустосвятом” Григорием Распутиным, дает, между прочим, ему следующую характеристику: "По настроению он - сектант, под видом лицемерного благочестия занимающийся соблазном и обольщением девушек и женщин...”» [33].

Не допуская, судя по всему, даже мысли о том, что гипотетический читатель может сочувствовать Распутину или относиться к нему, как минимум, нейтрально, Жданов описывает едва ли не как подвиг публичные нападки, которым подвергал Распутина священник села Покровского Петр Остроумов. При этом стремление Григория урезонить священника и наладить с ним доверительные отношения журналист сопровождает злорадно-оскорбительными ремарками. Любопытно при этом, что представитель либерально-антиклерикального издания фактически подкрепляет свою позицию авторитетом оплота российского клерикализма - Св. Синода, по слухам, тайно ополчившегося против «распутного старца». То, что в данном случае речь шла о вторжении церковных властей в частную жизнь человека и попрании базовых принципов свободы совести, зафиксированных во всех либеральных программах (так, в программе партии кадетов вторым пунктом - после равенства всех перед законом - значилось: «Каждому гражданину обеспечивается свобода совести и вероисповедания. Никакие преследования за исповедуемые верования и убеждения, за перемену или отказ от вероучения не допускаются» $[34,327])$, оставалось «за кадром»:

«Имея специальные директивы от Св. Синода, покровский священник (Остроумов), и ранее не церемонившийся с Распутиным, начал и с амвона, и частным путем беспощадно громить “экс-блаженного старца”, экс-гастролера.

А он, как затравленный зверь, не знает, что ему делать, куда броситься...

Вот любопытный документ, находящийся в моем распоряжении, - письмо "Григория" о. П. Остроумову.

Маленький клочок $(1 / 2$ листа писчей бумаги) уродливо записан крупными буквами (орфографию сохраняем):

“Отец [знак креста] (святой? - Д. К., Е. С.) Петр. Я бы лучше подумал тсцательно узнать а потом кделу приставить аложь непроведывать ато бог пожалуй осердится я много ошибаюсь всвоих странных поступках но поскорблю боженька услышит и успокоят акто клевещет того рожигаетнепокой даже иночью недает покоя етем безпокойством пользуется враг алутше помолиться авас необижал поетому инебоюсь яне расчитывал последнне дни выльется из ваших уст клевета Григорий”.

А сбоку, в виде post-scriptum'a: “Я любви не добиваюсь неотково а бегут и любят” " [31].

Все прочие свидетельства с родины Распутина у Жданова - сплошь анонимные, по сути, сливающиеся в один голос. Сам журналист, как бы невольно проговариваясь, именует своих экспертов «массой» (орфография первоисточника сохранена):

«Точным показателем мнения массы, безусловно, не признающей “святость” “святого старца”, служит то, что сколько я не расспрашивал разных крестьян о “святом" Распутине, все дают отрицательные, иронические отзывы» [27].

Учитывая факт явной «литобработки» прямой речи безвестных представителей упомянутой «массы», стоит лишний раз усомниться в достоверности данных свидетельств.

Один из анонимных әкспертов - крестьянин, якобы знавший Распутина, - говорит в пересказе Жданова как хорошо подготовленный оратор или, как минимум, провинциальный актер, которому поручено вещать «народной речью» и одновременно выписывать горгианские фигуры (такие, как ирония и сарказм):

«Такой же (т. е. отрицательно-иронический. - Д. К., Е. С.), но особенно любопытный отзыв о “старце” дал и тот “друг детства”, с которым мне совсем случайно удалось столкнуться в дер. Дубровной. Развитый, довольно начитанный крестьянин. (Состоит на службе по лесному ведомству.)

Спрашиваю, как будто невзначай:

- А скажите, пожалуйста, вашу деревню часто посещает Распутин из Покровского? Вы, вероятно, его знаете?

- Это Гришку-то Вытула? - хитро прищуривая глаза, спросил крестьянин.

- Да-да, "святого старца".

- “Святого”! Гм. Как не знать, знаем. Ведь мы вместе с ним четыре класса в "университете" прошли, а из пятого нас выгнали, - не без злого сарказма заговорил мой словоохотливый собеседник. 


\section{Исторический журнал: научные исследования № 4 (28) • 2015}

DOI: 10.7256/2222-1972.2015.4.17043

Он не без злой иронии добавил:

- Не святой он, а жулик!..

Деревня Дубровка, оказывается, испытала на себе, что называется, центр тяжести “подвижничества старца".

Здесь он нашел себе и невесту (жена Распутина - б. крестьянка дер. Дубровной, Парасковья Федоровна Дубровина).

Здесь же он нашел себе и последователей, вернее, последовательниц, а также устроил “главную квартиру” в доме кр. Екима Дубровина, когда уже сделался "святым старцем".

- Особенно часто наезжал сюда святой Вытул раньше. Приезжал, да всегда цельным поездом. И барыни, и господа все какие-то с ним из Петербурга... а он их здесь дурачил. Соберет их всех, молитвы заставит петь, а затем барабаться к барынькам-то полезет... Для того, значит, чтобы освятить их, - ехидно рассказывает крестьянин.

- А что это за собрания были у них?

- Да вот приедут все "святые”, а с ними иногда петербургские барыни...

- Почему вы сказали во множественном числе: святые?

- Так еще называют у нас трех тоже "старцев”. Такие богомолы, как и вытул.

- Кто же они такие?

- Николай Распутин, сродный брат Григория-то, затем Илья Арапов, высокий такой, рыжий мужик, в Покровском же живет, и еще Николай Распутин, из Подбулыги (дер. Никитиной). А то какой-то еще монах приезжал, имя его я забыл что-то...

- Илиодор что ли?

- Да-да, припоминаю теперь...» [27].

Вся эта грубая мешанина из псевдонародных фразеологизмов - «цельным поездом», «барабаться к барынькам» и др. - и интеллигентского «да-да, припоминаю теперь» заставляет усомниться не только в стилистической, но и в содержательной достоверности данного диалога. Особенно если принять во внимание грубые фактические ошибки. Так, анонимный знакомец Распутина упоминает о «сродном брате Григория», однако ясно, что для распутинских односельчан и соседей не могло быть секретом то, что Григорий - единственный ребенок в семье, по какой причине он, в частности, избежал армейского призыва. Как нетрудно понять, именно Жданов, а вовсе не его собеседник (если таковой вообще был) по банальной журналистской небрежности «умножил сущности», «пре- вратив» двоюродного брата Григория - Николая Распутина - сразу в двух распутинских братьевтезок: двоюродного и родного.

У другого анонимного собеседника Жданова - некоего лоцмана на пароходе, на котором журналист плыл в Тюмень, - также заметны нехарактерные для простолюдина выражения и обороты («красивая деваха», «кровь с молоком», «оголтелая дура», «ух как много!» и др.), подходящие не столько реальной народной речи, сколько плохой народнической публицистике и беллетристике. Данное обстоятельство вновь позволяет заподозрить, что эта речь также была, как минимум, сильно отредактирована автором.

«...Лоцманом на пароходе мне было рассказано:

- О Григории Распутине, господин, я знаю немного. Вот только то и могу говорить, что уж в нашей деревне (Артамоновой, по Тобольскому тракту в 37 км. от Покровского) доподлинно известно. А всего болтают здесь о нем ух как много! Так что даже за все, как правду, и поручиться нельзя. Ну, а вот как наших девок с деревни он, этот “святой”-то в монастырь загоняет, - сам знаю. Была у нас деваха такая, красивая, здоровая, кровь с молоком - Аграфена Меркурьевна. Веселая, хорошая - одно слово, нисколько на богомолку не походила. Это пока "святого" нашего не знала. Зато как узнала о нем, стала его часто навещать, захирела, красоту свою куда-то подевала, стала много Богу все молиться, о “святом” говорить, а потом совсем решила от мира отказаться и ушла в монастырь на житье. Ивановский монастырь - в 11 верстах от Тобольска. Что с девкой вдруг сделалось, так никто ничего и узнать не может. Только до того деваха была хорошая. Жила ли она со “святым" или не "освятилась” - ничего сама-то не говорит.

- Другая девка - Арина Прокопьевна Микурина - откровенней была. В прислугах будто бы у Григория жила наперво, а потом вместе с ним в богомольство и все прочее такое ударилась... Родные ее очень восставали против всего этого-то...

...Ей говорят, что, мол, срам будет, как ты, деваха, с ребенком будешь, а она это Богу молится и одно все отвечает: “Дивья бы в Григория-то Ефимовича сынка принести... Не грех!” Оголтелой дурой совсем стала и вскоре тоже в Ивановский монастырь ушла...

...Аграфена Меркурьевна - по фамилии 3аякина. Как о ней, так и о другой девушке, Микуриной, все данные подтверждаются вполне. 


\section{Исторические факты, события, феномены}

По-видимому, обе эти девушки - жертвы распутинского доктринизма.

Помимо этих фактов мне еще удалось установить факт нового “подвижничества” Распутина с его доктринерством.

Вот эти новые жертвы: “девица” Авдотья Захарова, крестьянка дер. Лысовой (50 верст от Покровского) и крестьянка дер. Дубровной П. Дубровина. Обе они теперь также в Ивановском монастыре» [35].

В данном случае обращает на себя внимание то, с какой легкостыю в своем стремлении развенчать Распутина Жданов переходит от вполне православно-клерикальных по духу претензий к нему как «сектанту» к вполне либерально-гуманистическим, по сути, антицерковным инвективам. Но еще примечательнее то, что сам журналист, похоже, этой коллизии не замечает, с одинаковым пафосом обвиняя Распутина как в том, что он заманивает людей в свою гипотетическую секту, так и в том, что он подталкивает их к уходу во вполне официальный православный монастырь. (Настораживает также и упоминание среди новых «жертв» некой П. Дубровиной из деревни Дубровиной. Вполне возможно, что, как в случае с двоюродным братом Николаем Распутиным, журналист вновь по оплошности произвел «удвоение сущностей», по ошибке причислив к числу «жертв» законную супругу Григория Распутина Прасковью Дубровину, уроженку деревни Дубровной.) Данный алогизм был характерен отнюдь не только для материалов Жданова, но для многих публикаций, посвященных распутинской теме. Как представляется, это являлось следствием изначального отношения большинства либеральных (и «желтых», что будет видно чуть ниже) изданий к личности Григория не как к самостоятельному объекту журналистского внимания, а как к средству, призванному прежде всего помогать оппозиции атаковать правительство, а заодно повышать газетные тиражи.

Сугубо анонимные свидетельства, к тому же полученные из вторых рук, использовал, хотя и с оговорками, как информационное сырье для своих статей и Володюша - корреспондент «желтой» «Уральской жизни». Как нетрудно заметить, главное, что привлекало его в распутинской теме, - это ее предположительный уголовно-криминальный след, на который удачно наслаивался флер политического скандала:

«Местные обыватели между тем делились с публикой слухами и легендами, окружающими жизнь “старца” на его родине.
Чиновник тобольской казенной палаты г. N рассказывал мне, со слов представителя местной администрации, что полиция давно уже озабочена тем, что происходит в доме "старца” в селе Покровском.

- Там происходит что-то невероятное... рассказывают, что женщины, которые гостят у “старца" под видом “сестриц", постепенно хиреют, чахнут и, наконец, умирают от неизвестной причины, причем наследство их переходит к Распутину... Да мало ли что еще рассказывают! Но все попытки местной власти поближе познакомиться с закулисной деятельностью "старца" систематически разбивались, благодаря его могущественным покровителям... Однако народная молва настойчиво связывает дом "старца" Григория со всякими мелодраматическими и уголовными ужасами... Правда это или нет - конечно, это лучше всего было бы установить формальному следствию...» [36].

Итак, все три автора стремились к знакомству со знаменитым «старцем», имея изначально различные мотивы и разный исходный информационный багаж. Во многом это определило и те обстоятельства, при которых состоялось знакомство, общение и расставание журналистов со старцем.

«Как познакомиться с этим субъектом? размышлял по собственным воспоминаниям А. Сенин. - В качестве политического, которого, как известно, новоявленные "святые" побаиваются и не особо долюбливают, мне это сделать было нелегко. Притворяться и лицемерить не было охоты...» [17]. В конце концов, Сенин решил воспользоваться посредничеством общего знакомого, обладавшего служебным авторитетом: «Вместе с начальником почтово-телеграфного отделения Н. В. Корняковым, приятелем Григория Распутина, направились мы к нему в гости» [37].

Будучи с самого начала откровенным с Распутиным относительно себя и своих идеологических взглядов, Сенин, по его словам, не стал скрывать и намерения опубликовать о нем материал. Правда, сообщил он об этом Григорию не сразу, а лишь после того как их общение уже подошло к концу и сам «старец» прямо задал соответствующий вопрос. Посредством использования нехитрых риторических приемов Сенину все же удалось получить от Распутина разрешение на публикацию материала:

«В последний раз я посетил Григория Нового в конце апреля 1908 г., услыхав, что на Пасху 


\section{Исторический журнал: научные исследования № 4 (28) • 2015}

DOI: 10.7256/2222-1972.2015.4.17043

он явился домой. Распутин чувствовал себя не совсем здоровым. Принял, однако, он меня довольно приветливо, хотя и не с таким радушием, как раньше. Причина этому скоро выяснилась.

- Как ваши дела с епископом (тобольским)? спрашиваю.

Григорий только рукою махнул: "Не принимает и не надо... кланяться не будем... пусть он верит разным россказням...”

- Ну, а как ваше “житие”? - продолжаю.

- Отложено, - говорит. - Вы тоже, вот, про меня напечатать собираетесь? Мне о. Федор (местный священник) говорил: смотри, выведает он все у тебя, да и отпечатает, затем, говорит, и бывает у тебя...

- А вы что же... боитесь?

- Н-нет... - замялся Григорий. - Чего мне бояться? Худого я ничего не сделал...

- По-моему, - говорю, - тоже: печати боятся одни плуты да мерзавцы... Так вы не будете в претензии, коли я действительно про вас напечатаю?..

- Нет, нет, - отвечал Распутин.

А сам волновался и нервно ходил по комнате. Так и расстались мы с Григорием Ефимовичем... Он снова уехал в Питер, а я остался с своей загадкой: кто он и что он?..» [29].

Диаметрально противоположный подход к знакомству и общению с Распутиным выбрал К. Жданов. Понимая, что затравленный либеральной печатью «старец» может не захотеть общаться с репортером одной из газет, представляющих этот лагерь, корреспондент «Уральского края» решил попросту обмануть Распутина. Судя по всему, этот свой ход кадетский репортер расценивал как весьма остроумный и этически безупречный:

«Мне ничего не оставалось больше делать, как сочинять небылицы для “святого старца". И я начал, что специально командирован сюда, в Покровское, от правых изданий узнать о жизни “старца” [38].

Получив желаемые сведения обманным путем, Жданов с демонстративным презрением покинул дом гостеприимно принявшего его Распутина:

«Отказавшись от предложенного чая, я распрощался со “старцем”. "Храни Бог!” - снова донесся до меня голос ханжи» [38].

Отдельно рассказывает Жданов и о том, как раскрыл свое инкогнито перед «старцем»:

«Встретившись с Распутиным второй раз на улице, я передал ему мою визитную карточку с “крамольными” газетами и сказал, что у него был в маске.

- Никто, как Бог! - оставаясь верным себе, произнес “старец"» [38]. Данную реплику, повидимому, следует понимать так: «Никто не праведен, как Бог, все не без греха».

Жданов не скрывает, что ему непонятны ни реакции, ни поступки «старца», которые вместо ожидаемо агрессивных оказываются доброжелательными и корректными:

«После того как я раскрыл перед Распутиным мои карты, мне, разумеется, и не приходила даже в голову мысль, что “святой” будет вновь приглашать меня к себе в гости.

Тем не менее, действительность превзошла все мои ожидания.

- Миленький, но ты заезжай все же ко мне в гости-то, - сказал он, увидя меня на улице; сказал хотя вкрадчивым голосом. - Никто, как Бог...

- Благодарю. Зайду, если удастся, - не без усилия ответил я “старцу”» [39].

Корреспонденту «Уральской жизни» повезло больше его коллег - он повстречался с Распутиным, интерес к которому испытывал уже давно, случайно (на этот раз инкогнито до определенного момента старался сохранить «старец»). И хотя он описывает, что с первых секунд знакомства Распутин произвел на него крайне неприятное впечатление, сами обстоятельства встречи невольно характеризуют «старца» как приветливого и вежливого человека:

«Это было недели две тому назад.

Поезд приближался к Тюмени, когда дверь купе отворилась и бледный худой незнакомый человек обратился ко мне со странным вопросом:

- Можно поискать у вас моего ежика? Он убежал...

- Пожалуйста!

Помню, сквозь полудремоту раннего утра меня удивили необычные интонации в голосе этого человека и его внешность - внешность юродивого и разбойника вместе.

Что-то слабо дрогнуло в глубине моей памяти: положительно я раньше видел это лицо! Но где же, где?

Пока незнакомец шарил под диваном в поисках за своим ежиком, я наскоро старался вспомнить, где и когда я его видел.

Было ли это в действительной жизни, или он только напомнил мне художественный или литературный образ?..

....Между тем незнакомец уже стоял передо мной с пойманным зверьком в руках и улыбался 


\section{Исторические факты, события, феномены}

своей истерической блаженной, лукавой и неискренней улыбкой.

- Поймал. Извините за беспокойство... Далеко ли едете?» [36].

Ответил ли он на вопрос Распутина, Володюша не сообщает. Вместо этого он говорит, что начал пристально разглядывать смутно знакомого собеседника (вероятно, в этот момент в лице бородатого человека, держащего ежика в руках, Володюше и привиделась «истерическая блаженная, лукавая и неискренняя улыбка»):

«Нескрываемое любопытство, с которым я его разглядывал, было ему, по-видимому, неприятно.

И әта черта вдруг заставила меня вспомнить о нашей первой встрече...

Это было летом прошлого года в поезде между Пермью и Екатеринбургом. Внимание всех пассажиров было тогда привлечено странной группой из нескольких прилично одетых женщин различного возраста, среди которых был только один мужчина - мой теперешний знакомый незнакомец.

Он держался с ними как богатый наследник с бедными родственницами.

А они ухаживали за ним, водили его под руку, ходили за ним как за ребенком... И вместе с тем в его отношениях к ним смутно чувствовалось что-то нечистое, эротическое, извращенное.

Я напомнил своему собеседнику о прошлогодней встрече.

Он неохотно ответил:

- Может быть, это был и я... Я часто езжу...

Тут у меня впервые мелькнула мысль:

- Уж не старец ли это Григорий Распутин, о котором так много говорят и пишут?..

Поезд остановился в Тюмени. Мы расстались» $[36]$.

Рассказ Володюши выглядит не вполне правдоподобным в той части, где журналист описывает себя и свои переживания. Вряд ли мысль о том, что год назад он видел именно Григория Распутина, о котором «так много говорят и пишут», пришла Володюше в голову только во вторую встречу и лишь после того, как он изучил зловещую улыбку вошедшего в купе якобы незнакомца. Скорее всего, журналист и тогда, и особенно теперь, увидев Распутина, довольно быстро понял, кто именно стоит перед ним, а все свои впечатления, размышления и переживания отчасти додумал и «драматически оформил».

Дальнейшая «охота» Володюши на Распутина вполне соответствует поведению журналиста «желтого» издания, ищущего материал для бульварной сенсации.

«На следующее утро пароход Западно-Сибирского пароходства “Ласточка" готовился отойти из Тюмени в Тобольск.

Я, волнуясь, ждал старца Григория. В том, что мой вчерашний спутник был именно он я уже больше не сомневался.

В кармане моего пальто лежала столичная газета с портретом “старца”, в котором нетрудно было узнать характерное лицо моего собеседника.

Я знал, что старец Григорий живет в селе Покровском тюменского уезда и что летом в это большое и богатое село ездят на пароходе. Словом, я имел все основания волноваться в ожидании интересного “интервью” с религиозным авантюристом нашего времени.

Я не ошибся в своих ожиданиях. Григорий Ефимович появился на пароходе незадолго до его отхода вместе с мальчиком лет 14-ти, как я впоследствии узнал - его сыном, воспитанником саратовской духовной семинарии. У мальчика было рядовое здоровое и круглое лицо, какие бывают у подростков небогатого купеческого круга, но в глазах и в улыбке гнездилось что-то "распутинское", какое-то тайное знание и преждевременное лукавство...

Они заняли каюту 1-го класса.

Теперь моя задача состояла в том, чтобы продолжить вчерашнее знакомство и вызвать “старца" на откровенную беседу.

В ожидании я вышел на дэк.

Пароход медленно плыл по узкой ленте Туры, почти у самых берегов.

Светило матовое северное солнце, и в утреннем воздухе весело и возбуждающе звучали обычные пароходные шумы.

Через некоторое время “старец” появился на дэке, мы раскланялись, и разговор завязался...» [36].

Описанную как забавное приключение встречу с Распутиным Володюша завершает явно тщательно выписанным эпически взвинченным финалом, в котором Распутин предстает как некая метафора всего дьявольского, что сковывает т. н. здоровые силы общества, а не как реальный человек.

«Пароход причалил к берегу.

- Село Покровское!

Публика бросилась к мостику, чтобы лучше видеть сцену встречи “старца" Григория с домашними. 


\section{Исторический журнал: научные исследования № 4 (28) • 2015}

DOI: 10.7256/2222-1972.2015.4.17043

Его встречали две девочки - его дочери, жена и две женщины в черных платочках.

Он поцеловался с девочками и, не обращая никакого внимания на жену, которая обняла его было за шею, чтобы поцеловаться, и на других женщин, которые стояли поодаль, пошел с девочками к экипажу.

Экипаж тронулся. Три женщины покорно следовали за ним пешком.

На фоне вечереющего неба четко вырисовывались их фигуры в простых черных одеяниях...

Публика на пароходе делилась впечатлениями от этой странной встречи.

Экипаж Распутина скрылся за пригорком.

- Конец распутинской эпопеи! - Звонко крикнул студент вслед экипажу.

- Аминь! - строго и серьезно сказал священник-миссионер и посмотрел на молчаливое холодное небо...» [36].

Так как с корреспондентом «Уральской жизни» Распутин общался в пути, описать домашний быт «старца» у Володюши возможности не было. А вот авторы «Уральского края» и «Южной зари» довольно подробно останавливаются на этой теме.

К. Жданов, несмотря на напряженный поиск порочащих «старца» деталей, о доме Распутина почти ничего плохого сказать не смог. Более того, фактически вынужден был признать, что его коллеги по кадетской печати из «Речи» сильно погорячились в описаниях «роскоши» распутинской жизни в Покровском.

«Высокий, деревянный, на каменном фундаменте дом Распутина в Покровском вполне претендует на хорошую городскую усадьбу, но назвать его - как по величине, так и по архитектуре "первым на селе" - нельзя, безусловно.

Правда, два этажа больших окон, красиво включенных в массивно выпуклые наличники, приличная (хотя по-деревенски пестрая) окраска, палисадничек, - все это в общем составляет о доме достаточно выгодное впечатление.

Но, читая прежде проникавшие в печать преувеличенные сведения о роскоши дома Распутина, по которым можно было представлять какие-то хорошие боярские хоромы, пожалуй, даже целую гостиницу, вмещавшую в себя - помимо семейных Распутина и его 12 "сестер", располагающих каждая по комнате, - еще "массу столичных гостей”, - невольно разочаровываешься: дом "святого старца" очень скромных размеров.
Фасадом в 3 окна дом едва ли занимает даже полных 2 сажени. Вглубь усадьбы - идет сажени на 4.

Внутреннее помещение довольно ограниченное: в верхнем этаже - большая комната и две маленьких, а в нижнем - кухня и также две маленьких комнатки.

Разумеется, и это все очень и очень даже не походит на жилище "святого", хотя бы и в кавычках, особенно обстановкой» [30].

Исправляет Жданов и другие слишком явные ошибки «Речи», касающиеся, в частности, семейного состава «старца», а также слухов о «редкой красоте» его поклонниц.

«От своей законной супруги - Парасковьи Федоровны (кр-ки из дер. Дубровной, Тюм. у.), по-видимому, когда-то крепкой, здоровой женщины, а теперь с болезненным выражением и на лице, и во всей натуре, - Григорий Распутин имеет 3 детей. (В печати за последнее время прошли неточные сведения.) Сын - Дмитрий, 12 лет, и две дочери - Матрена, 11 лет, и Варвара, 9 лет».

Следует отметить, что возраст Дмитрия и Матрены указан Ждановым неверно. Даты рождения детей Г. Е. Распутина: Дмитрий 25.10.1895 г., Матрена - 26.03.1898 г., Варвара 28.11.1900 г. [40,113].

«Причисляет к своему семейству “блаженный” святоша и двух постоянно живущих у него “сестер”, которых “духовно” он любит. Обе они пожилых лет, некрасивые, живут в качестве пострадок (работниц), но отправляют свои обязанности безвозмездно» [30].

А. Сенин сосредоточивается на внутренней обстановке распутинского дома, подробно и беспристрастно описывая детали:

«По чисто вымытой деревянной лестнице, устланной разноцветными половиками, мы поднялись во второй этаж. Маленькая, чистенькая приемная, большой, устланный тоже половиками зал, в нем превосходный письменный стол, мягкая мебель, дубовый массивный буфет, все новое, блестящее. Под окнами солидные фикусы. Стены оклеены обоями, в углу большие иконы с лампадками, превосходной работы в золоченых рамах портреты Высочайших Особ. Масса фотографических снимков, на которых фигурирует сам Григорий Ефимович.

Вот он среди профессоров и студентов Петербургской духовной академии, посреди преподавателей духовных учебных заведений, среди игуменов, архимандритов и архиереев, вот он с О. В. Лохтиной, со священником петергофской 


\section{Исторические факты, события, феномены}

пересыльной тюрьмы Медведем, который, кстати сказать, гостил у Григория целое лето. Вот сидит Григорий на стуле, а сзади него почтительно стоят два блестящих придворных генерала Путятин и Ломан.

И не как-нибудь снят Григорий Ефимович, а всюду и везде - центральная фигура: серый, невзрачный, с большим носом, грубый сибирский мужик в одной русской рубахе или в синем деревенском кафтане...

А на письменном столе, на самом первом месте большой портрет о. Иоанна Кронштадтского, за ним великих князей Петра Николаевича, Николая Николаевича, Анастасии Николаевны, принца Ольденбургского, архиерея Сергия, Антония Волынского и друг. Водятся и книги у Григория Ефимовича, но исключительно духовные; светских книг и газет в его доме не полагается» [37].

Контраст с описанием кадетского репортера, как нетрудно заметить, - весьма существенный. Ни единого уничижительного эпитета, предельная внимательность к деталям, скрупулезная достоверность в их передаче. И в то же время - умение показать через эти, казалось бы, сугубо материальные аксессуары быта главную черту в характере героя: его стремление всегда быть в центре внимания окружающих, особенно высокопоставленных персон [41, 24-42]. Также из описания дома становится очевидным и желание «старца» подчеркнуть свою близость в первую очередь к православным священникам и иерархам.

Эти же качества хозяина дома ясно проглядывают и сквозь описание чаепития, также сугубо фактологичного и лишенного каких бы то ни было этических оценок и характеристик.

«Но вот, подали чай. Пригласили нас в столовую. Уселись мы за большой круглый стол. Явилась жена Григория Ефимовича, больная, испитая, но очень бойкая женщина лет 40. Два раза она ездила уже в Петербург, где ей делали какую-то операцию. Рассказывает, что и во дворце была... Пришла Берладская, симпатичная, с интеллигентным лицом, просто, но со вкусом одетая, маленькая, прихрамывающая на одну ногу, видимо, измученная чем-то женщина лет 30-35. Явились три-четыре “сестры” в платочках, приветливы, ласковы и с нами, и между собой. Держатся просто, скромно и непринужденно. Пришел Илья Арапов. Появились на столе самовар, пироги, булочки, конфеты, семечки, орешки (“сибирский разговор”), фруктовая вода. Мальчик лет 12 и девочка лет 10, дети Распутина, учащиеся в местной школе, вздумали было наклеить какую-то картинку светского содержания на стену. Отец и мать воспротивились. На одном из столов увидал я книгу и справился - какая. Оказалась Библия.

- А это вот, - указал Григорий на другую книгу, - житие мое.

Оказалось, что Берладская со слов самого Распутина пишет его “житие”, которое предназначено для печати.

Чай был кончен. Все чинно расселись по местам и началось пение. "Братья и сестры” под руководством Григория начали: “Спит Сион и дремлет злоба: спит во гробе Царь царей...”

Выходило стройно, гармонично и красиво. Товарищ мой с чувством подтягивал басом. Создавалась таинственно-благоговейная атмосфера, точно в храме. А хор трогательно и с чувством начинал уже новый стих на церковномонастырский грустный напев: "Не унывай, не унывай, душа моя, уповай ты на Господа”.

Тонкие женские голоса печально и нежно переливались, им глухо и грустно аккомпанировали басы. Мирное, спокойное настроение создавалось в душе... И становилось жаль чего-то... жаль до бесконечности... И в сердце заползала тихая, непонятная грусть...

Поблагодарив хозяев, простившись с "сестрами”, около полуночи мы направились домой» [37].

Но, наверное, лучше всего различия в подходах разных репортеров к встрече с Распутиным и к распутинской теме как таковой проявляются в описаниях внешности «старца».

Наиболее четок и лаконичен А. Сенин. Созданный им словесный портрет «старца» напоминает методичное составление фоторобота:

«Самая заурядная физиономия сибирского мужика лет 40-45; худощавое загрубелое лицо, окаймленное темно-русой бородой клином, большой нос, грубые черты лица, развитые челюсти, глубоко сидящие серо-голубые глаза, очень мутные; цвет лица испитой и не совсем здоровый; русые волосы в скобку, суконная поддевка, лакированные бутылками сапоги» [37].

К. Жданов описывает облик «старца», стремясь достичь максимального «оппозиционного эффекта». С этой целью журналист намеренно смешивает внешние и этические характеристики, а также присовокупляет к ним фактуру, касающуюся близости «старца»к царской семье: 


\section{Исторический журнал: научные исследования № 4 (28) • 2015}

DOI: $10.7256 / 2222-1972.2015 .4 .17043$

«Сам "старец" имеет от роду 42 года, как об этом свидетельствует выписка из метрической книги, находящейся при церкви села Покровского».

Жданов вновь допускает фактическую ошибку: согласно метрическим книгам, Г. Е. Распутин родился 09.01.1869 г. [40, 112]. Таким образом, в июне 1910 г. ему был 41 год.

«Среднего роста, узкоплечий, худощавый, с широкими (“открытыми”) серыми глазами, глубоко впавшими в орбиты, “блаженный старец” сразу и во всем проявляет себя, как святоша.

Тон и тактику ханжи он не оставляет, кажется, никогда.

Одевается он обычно в рубашку-косоворотку, черные брюки и высокие лаковые сапоги. В парадные дни “блаженный” пополняет свой туалет нагрудным крестом, пожалованным ему от Государя. Это - золотой массивный крест с изображением распятия Иисуса Христа и с надписью на одной стороне - "Спаси и Храни", а на другой - “Николай II"» [30].

Следует подчеркнуть, что именно в данном газетном тексте присутствует первое открытое медийное упоминание имени российского императора в «распутинском контексте». По сути, этот момент и являлся сенсационным гвоздем публикации.

Все дальнейшие рассуждения Жданова дефакто получали вполне конкретную политическую заряженность, направленную прямо против Николая II и Александры Федоровны:

«Ввалившиеся в обведенные предательской синевой орбиты глаза Григория Распутина на людей слабонервных производят “сильное впечатление". Разумеется, такое влияние “блаженный старец” может иметь только на слабых $<\ldots>$ да преимущественно еще на истеричных барынек... Поддающиеся "гипнозу" распутинских глаз жертвы - жертвы самовнушения. У Гр. Распутина не сильный взгляд, а просто нездоровый» [30].

Описание же Распутина журналистом «Уральской жизни» Володюшей представляло собой характерное для «желтых» изданий хаотичное нагромождение гротескно преувеличенных деталей, создающих в итоге образ демонического существа:

«У него есть какое-то сходство с репинским Иоанном Грозным; такие лица встречаются на полотнах Ге; помнится, нечто подобное попадалось в суриковских типах Московской Руси... $<\ldots>$ Его маленькие, глубоко ввалившиеся серые глаза смотрели остро, пристально, с неверной нарочитой ласковостью. Было в них чтото нечистое, ускользающее и вместе упрямое, хищное и гипнотическое.

Его большой влажный и порочный рот улыбался, показывая два ряда крупных желтых зубов. Серое, землистое, измятое лицо с грязно-русой бородой и такими же волосами, подстриженными в скобку, - было бы даже приятно, если бы не его выражение - поразительное сочетание елейной святости с разнузданной животностью.

На вид ему можно было дать лет сорок. Он был одет в грязную чесучовую рубаху, летнее пальто и черный картуз» [36].

В беседах с журналистами Распутин проявлял себя неодинаково. Однако во всех случаях он демонстрировал такие качества, как коммуникабельность, непосредственность (не выходящая, правда, за рамки вежливости), априорная расположенность к собеседнику, подчеркнутая откровенность, готовность максимально подстроиться под него (избегая, впрочем, льстивого заискивания), учесть его личные особенности и поддерживать предложенные темы обсуждения.

Разумеется, каждый из репортеров использовал эти качества Григория как собеседника по-разному - в соответствии с исходным «творческим замыслом».

Описывая в «Южной заре» свою первую встречу с Распутиным, А. Сенин сразу отметил в Распутине стремление выразить ему сочувствие именно как политическому ссыльному:

«Любовно, радушно встретил нас хозяин, расцеловался с моим товарищем и все остальное внимание сосредоточил на мне. Без тени какой-либо неловкости и застенчивости Григорий Ефимович прямо и просто обратился ко мне.

- Ну, что, миленький, долго еще страдать-то здесь придется? (Ему, очевидно, уже кто-то раньше отрекомендовал меня). Что делать?.. Много и хороших людей пострадало... Как их различить?.. Но только больше года ты здесь не пробудешь... Всех, кто не грабил, не убивал, через год отпустят, - проговорил хозяин и при этом говорил то “ты”, то “вы”.

Все местные обыватели на “ты” между собою.

- Вам лучше, - говорю, - знать, когда нас отпустят - вы в столице живете» [37].

Перевод разговора на его личность Распутин поддержал с готовностью: 


\section{Исторические факты, события, феномены}

«Григорий сразу оживился и весьма охотно и с увлечением начал рассказывать про свою петербургскую жизнь.

- Ну, что?.. Не говорил я вам, - выпалил мой товарищ, - что Григорий Ефимович простяга, сам все расскажет и ничего не скрывает... А ты, Григорий Ефимович, не бойся, расскажи Александру Ивановичу все, очень уж ему хочется знать, как ты из челдонов, да так высоко поднялся.

- Ничего я, миленький, не скрываю, - адресовался Распутин ко мне. - А что делаю, все на виду... Тяжело мне здесь... Сплетничают они... А тянет к родине-то, хотя отвык уж я от крестьян... и они не так смотрят на меня... Да и батюшки не ладно делают... А почему? Темные они люди, и батюшки темные, и не могут понять любви... Разве такие люди там, в Петербурге?.. Мои знакомые там все знатные, да богатые и образованные... Раз он сказал тебе что или подумал что о тебе - не изменит...

Распутин с трудом подыскивает слова, лицо его при этом передергивается, глаза блуждают и как бы стараются уловить в воздухе ту фразу, которая бы выразила его мысль.

- Я умный и “братья” мои умные, мало они только путешествовали и людей видели... Взять хотя бы Илью (брата)... одно слово сказать, и сейчас бы во священники посвятили, да сам не хочет, боится... Много про нас, миленький, дурного говорят..

- Да, я слышал, - отвечаю.

- Как, миленький, не слышать!.. Нехорошо батюшкам под окнами бегать, да подглядывать... Но я не жалуюсь на них... И когда в Питере меня спрашивают про них, я отвечаю, что самые обыкновенные попы... Завидуют они мне, почему не с ними, а со мной, с простым мужиком, имеют дело и знакомство такие знатные люди... За доходами они лезут... вот что, миленький... А ты полюби сначала человека-то, да дело ему сделай, пользу ближнему от всего сердца своего, и все тебе будет...» [37].

Не дожидаясь «традиционного» вопроса об отношениях с женщинами, Распутин сам поднимает эту тему и излагает Сенину свою философию, которая, несмотря на религиозный контекст, в идеологическом плане оказывалась скорее основанной на принципах стихийного гуманизма. А в инструментальном отношении представляла собой разновидность психотерапевтического лечения неврозов. Следует подчеркнуть, что в данном случае Распутин высту- пал как психотерапевт-самородок, поскольку никаких специальных знаний об этом методе он иметь не мог: на Западе психотерапия (включая психоанализ) делала в ту пору лишь самые первые шаги, а в российской медицине данное направление получило развитие уже в послереволюционный период [42, 262-281].

«Ищите прежде всего Царствия Божия и правды Его, все остальное приложится вам... “Правды ищите", сказал Христос... А погонишься сперва за деньгами, ничего не увидишь... Жадны они у нас... Темные люди... Жалею я их... триста вер на свете - триста истин... Одна истина любовь... Она, как весна, все оживляет... Женщины, говорят они... Зачем ты, Григорий, с женщинами постоянно?.. - спрашивают они. А женщина разве не такой же человек?.. Их любить не надо?.. "Не прикасайся!..” - сказал Христос Магдалине по воскресении... На это упирают они... А при жизни разве одни ученики у него были?.. Разве не было у него учениц и разве не прикасался Христос к ним?.. Жизнь - в любви... Утешь душу - и успокоится, поверит человек... Нет такого человека, которого бы нельзя было заставить поверить и утешить... Хотя с настоящими неверующими плохо... Трудно их заставить поверить... Будешь говорить с ними, меньше всего упоминай про Бога... О Нем они знают лучше всякого попа, а ты в душу загляни, успокой и, главное, полюби, узнай, отчего страдает человек... Не любишь, не можешь полюбить человека - ничего не выйдет... Много я спорил по этому предмету с ихним братом: с попами, с игуменами, с архимандритами, архиереями... Они меня буквой, а я их жизнью, сердцем... У каждого человека в душе своя библия... Это - совесть... Ее не изменишь и от нее не увернешься... Спорил раз так-то с Антонием Волынским... и до того я довел его, что он стакан с чаем опрокинул... А чтобы понять душу человека, полюбить его, самому надо много перестрадать. Пил я раньше-то шибко, а потом бросил и всю свою жизнь перевернул... Трудно это было... И когда пил, то много страдал и все думал - думал, что живу не ладно... И мысль, что по иному нужно жить, никогда меня не покидала... А теперь, вот, сам утешаю страждущих... Главное, душу у человека надо узнать, чем она страдает, а потом и лечить. Трудно это... ох, как трудно!.. Потруднее, чем дрова в лесу рубить... А женщина... разве не страдает?.. не нуждается в утешении?.. Не могут они этого понять, что иначе можно любить женщину, как у вас, вот, например, у социалистов...» [37]. 


\section{Исторический журнал: научные исследования № 4 (28) • 2015}

DOI: 10.7256/2222-1972.2015.4.17043

Получив исчерпывающую информацию по «главной» распутинской теме, Сенин поинтересовался обстоятельствами жизни «старца» в Петербурге, его мнением о происходящих в столице и в стране событиях, его отношением к политикам и церковнослужителям. При этом целью автора, насколько можно судить, не являлось выяснение связей «старца» с царской четой и близкими к ней людьми. Об этой теме речь в беседе зашла лишь вскользь:

«- А где вы живете теперь? - спрашиваю.

- В Александро-Невской лавре, миленький... - Любят меня там... Не все, положим... Половина за меня, а другая против... И знакомые мои знатные, ученые... Там я при академии и живу, там и больных, нуждающихся в утешении, принимаю... Трудно мне, миленький... До двух часов каждый день у себя принимаю, а потом по больным да по знакомым разъезжаю... Часа три в сутки свободных имею, не больше.

- Какие же больные у вас бывают?..

- Всякие, миленький, всякие... А больше женщины... нервные все... из заграницы даже приезжают...

- Ну, а как же вы узнаете, чем болен человек?..

- А смотря по тому, какой человек... проникнуть нужно... И пока в душу к нему не заглянешь, что можно сказать?.. А трудно это, ах трудно!.. У всякого свое горе... И труднее всего заставить поверить... Многие вот в святых не верят... А как в них не верить? У Бога ничего даром не пропадает... Взять хотя бы ваш труд - ученье. Учится человек, старается, и за то ему свидетельство дают, права получает, образование. Так же и перед Богом-то. За святую жизнь - нетлением Господь награждает... А отсюда вот мощи, монастыри... Да что теперь наши монастыри!..

Распутин безнадежно махнул рукой.

- Если хорош ты был в миру, иди в монастырь - там испортят... Не по душе монастырская жизнь... Насилие там над людьми... Есть и там хорошие люди, вот, например, Никита на Валааме, но не любят их монахи и заставляют жить по-своему. Вот, хоть бы Троице-Сергиева лавра: нужно одеваться, в сермяге неприлично, надо приноравливаться и к уставу, и к публике... А выходит, ведь, лицемерие... А по-моему, все простится: и воровство, и убийство, и блуд, а лицемерие - никогда... Строго нужно следить за душой и без дела любви ее не оставлять...

- А почему же вы, Григорий Ефимович, не занимаетесь делами любви здесь, в деревне?
- А потому, миленький, что не поймут меня здесь... А там люди нервные, больные, понимают меня и нуждаются во мне...

И он передал о своих отношениях к нескольким высокопоставленным лицам, рассказал о своих связях в так называемых сферах.

- Ну, а Дубровина и Крушевана (А. И. Дубровин (1855-1921), П. А. Крушеван (1860-1909) - лидеры Союза русского народа. - Д. К., Е. С.) знаете? - спросил я между прочим.

- Не люблю я их... Худо они делают... Худо это... кровь...

Геннадий (возможно, имелся в виду Геннадий (Туберозов), в 1909-1914 гг. епископ Балахнинский, викарий Нижегородской епархии. Д. К., E. C.) - вот хороший человек. Гермоген вот - тоже.

Помолчали» [37].

Как нетрудно заметить, видя, что перед ним сидит приверженец социалистической системы взглядов, Распутин в очередной раз пытается найти точки соприкосновения с собеседником, чтобы поддержать интерактивный формат беседы. Следует специально подчеркнуть, что речь в данном случае идет не о лицемерном поддакивании или заискивании, а об умелом и тактичном использовании реальных точек соприкосновения, позволяющих войти с собеседником в доверительный контакт, при этом сохраняя приверженность своей системе взглядов.

Политические настроения Распутина - не только в церковном, но и в других вопросах можно охарактеризовать как умеренно-народнические, хотя и отчетливо антиреволюционные, компромиссно-реформаторские:

«- А народ точно бедствует, - сам уже начал Распутин, - был я нынче осенью в Смоленской губернии, у евреев. И беднота-та же, Господи!.. Одной селедочкой да кусочком хлебца целый день сыты, а я думал, что все они богатые, пока сам не увидел... Отпустят... Скоро вас отпустят, снова пророческим тоном и совершенно неожиданно проговорил он. - Кто не поджигатель, да не разбойник, через год отпустят...

- Почему же вы думаете, что через год?

- Время все уладит, миленький, вразумит людей...

- Ну, как тут вразумишь? Из-за нужды ведь народ-то волнуется, не по доброй воле...

- А я и не говорю, миленький, что наставлениями вразумишь... Дело вовсе не в наставлениях... А одна сторона уступит и другая - вот и умиротворится народ... Ведь, что было-то 


\section{Исторические факты, события, феномены}

там после 17 октября... Сколько народу в обморок упало при Дворе-то!.. Все это ведь Витте наделал... Витте - это мазурик и хитрый человек... Просить надо было честью, а не силою брать, - говорит он дальше. - Знаю я и забастовщиков... хорошие есть люди и самого настоящего добра народу желают, хотят устроить жизнь так, что и лучше не надо, да разве возможно это?..» [37].

Завершается разговор самой приятной для Распутина темой - его статусным положением в столичном обществе. При этом явное хвастовство «старца» Сенин воспринимает без встречных негативных эмоций, почти бесстрастно - просто перечисляя в косвенной речи озвученные Распутиным факты и никак их не комментируя:

«И снова он перешел на свою петербургскую жизнь, как почитают его там и ценят.

Ходит он там в шелковых рубашках, которые ему дарят. Ест он там без вилки, прямо рукою, и, если случится, что капнет на рубашку, шьют новую. Есть у Григория и шляпа, и пальто, и модные ботинки, и одевается он иногда франтфрантом, имея большую охоту походить и по костюму, и по манерам, и по выговору на барина. Плохо ему это удается и доставляет немало хлопот и огорчений. Но, являясь перед некоторыми высокими лицами, Григорий, говорят, носит вериги, холщовую рубашку, портки.

Круг знакомства между высшими духовными лицами у Григория громадный. Показывает он письма от архиереев, ректоров, архимандритов. Между прочим, томский архиерей звал его в гости... И в письмах везде, как я уже говорил, приписки: “Помолись за нас, святой отец” " [39] .

Зато о собственных впечатлениях от знакомства со «старцем» Сенин пишет очень эмоционально, стараясь быть максимально искренним:

«Все виденное и слышанное произвело на меня крайне сильное и досадно неопределенное настроение: мирное, тихое житие, святость на словах, высоконравственные начала из уст грубого сибирского безграмотного мужика, передовой взгляд на серьезные спорные вопросы жизни и тут же рядом эти слухи, компрометирующие Григория, его нездоровый цвет лица, мутный взгляд, его юродство, - все это создавало такой сумбур в моей голове, что разобраться в нем и вывести какое-либо определенное заключение я положительно не мог.. Кто такой этот Григорий?.. Хитрый и ловкий пройдоха-святоша или в действительности верующий и много чувствующий человек?..

Искренно говорил он со мною или лицемерил? И вспомнилось мне, как часто во время разговора менялось лицо Распутина. То делалось оно унылым и мрачно-серым, и тогда оно было неприятно, то вдруг оно просветлеет, оживится, и тогда речь его проникает прямо в душу...

- Ну, что?.. Ведь правду я говорил: хороший он человек? - спрашивал товарищ.

Я промолчал... Да и что я мог ответить?..

Разве одно - на человека неискушенного, а в особенности с приподнятыми нервами Григорий Распутин может произвесть даже чарующее впечатление... Для меня же он явился теперь большею загадкою, чем раньше.

На другой день он уехал в Петербург. Провожали его - жена, дети, “сестры” и “братья” [37].

После первой встречи Распутин все еще остается для Сенина человеком-загадкой, особенной личностью, непохожей на других, во многом мифологической. Это впечатление скорректируется во время второй их встречи. Она произойдет уже при совершенно других обстоятельствах - а именно, вскоре после описанного выше обыска у Распутина в 1908 г. Тогда автор увидит в Распутине обычные человеческие черты: возмущение учиненной против него акцией, обиду и злость на организаторов обыска, уязвленное самолюбие и в то же время готовность ради выгоды примириться с обидчиками в частности, принять приглашение миссионера Глуховцева заехать на чашку чая:

«На другой день я был у Григория.

Как сам он, так и гости были страшно возмущены обыском.

- И какое зло они могут мне сделать? - говорил Григорий. - Если посадят меня в тюрьму или иное какое зло причинят, это послужит только к моему возвеличению.

На чай к миссионеру решили, однако, заехать. Григорий был по-прежнему ровен и внимателен ко мне, но я скоро ушел: собрались местные полуинтеллигентные дамы, монашенки с разным товаром, Берладская открыла книгу и начала писать “житие”...» [29].

Свои новые впечатления от встречи с Распутиным на этот раз Сенин описывает кратко: «Кто и что Григорий?.. - по-прежнему оставалось загадкой. Только впечатление изменилось: насколько интересен он мне раньше казался, настолько же скучен, монотонен и сер теперь, при втором визите. 


\section{Исторический журнал: научные исследования № 4 (28) • 2015}

DOI: 10.7256/2222-1972.2015.4.17043

"Иоанниты!.. Черные вороны!" - мелькало у меня в голове, но... неужели может быть так искусно лицемерие?.. и в ком же? Грубый, безграмотный челдон... А, может быть, он только слепая игрушка в более ловких, умелых руках? Все может быть...» [29].

Репортер «Уральского края» К. Жданов, как уже было сказано выше, добился знакомства с Распутиным при помощи обмана - он выдал себя за корреспондента правых изданий. И в начале беседы Жданов делает вид, что солидаризируется с Распутиным в его противостоянии с левой печатью, однако в публикации сразу поясняет, что в данном случае намеренно лукавил, продолжая вводить собеседника в заблуждение.

«Ведь Вам, разумеется, известно, что печатается теперь про Вас в газетах, преимущественно в левых... Вот выдумали, что у Вас 12 "сестер" в доме живет, причем, каждая комнатой располагает. А между тем, у Вас и дом-то не такой большой.

- Да, напраслины на меня наводят. Живут у меня всего две сестры и духовные дочери, как я называю их, - начал было откровенничать "святой”, но спохватился и тут же пояснил. - Надо вам сказать - жена у меня больная, гостей у меня бывает много и часто. Особенно вот по праздникам и воскресеньям, как сегодня, например. Готовить на кухне нужно много, конечно, жена не могла бы. Вот и приходится иметь помощниц.

"Помощницы жены - удачное определение!” - пронеслось у меня в мыслях.

"Блаженный" же продолжал:

- Вы видели на кухне народ-то сидит?! Это все - гости, хотя и, правда, простенькие. Сегодня от обедни, как и всегда, ко мне направились прямо поесть да попить. Всех принимаю. Богомольцев много бывает. Добро все хочешь людям сделать, а на тебя клевещут! Но ничего. Никто, как Бог! - патетически заключил свою мысль “старец”, предлагая мне продолжать» [16].

В отличие от Сенина, выяснявшего взгляды и мнения Распутина в непринужденной беседе, Жданов предпочитает стиль «наукообразного анкетирования», вероятно, не умея, да и не желая вести разговор с учетом культурных особенностей собеседника:

«- От вас лично мне хотелось бы получить ответ на вопрос, касающийся теоретического оправдания некоторых ваших поступков. Например, относительно совместного вашего хождения в баню с женщинами для испытания лишь своей плоти. Правда, теория эта от вас исходит?
- Как, теория? Это я не совсем хорошо понимаю, - попросил объяснить слово “теория”, которое “блаженный”, вероятно, не только много раз слышал, но, несомненно, употреблял и сам.

Но, допуская возможность того, что он искренно задавался обращенным ко мне вопросом, я начал:

- Теория - учение. Созерцательное настроение, обнимающее своим объяснением какойлибо определенный круг обстоятельств.

- Понимаю, понимаю. Я и знал, только не так сначала вас понял, - остановил меня "старец”, а затем ответил и на повторенный мною вопрос. - Да, правда. Именно, нетрудно бросить курить табак, если его нет, а трудно вот это сделать, когда кисет переполнен махоркой или папиросами. Так и с соблазном прелюбодеяния. Нужно видеть голую женщину - пусть разгорается страсть, - а власти давать своей плоти не должен. Удалившись в пустыню, нетрудно святую жизнь вести» [38].

Распутин не отказывается объяснить Жданову свою философию, но, очевидно, почувствовав в собеседнике затаенную враждебность, делает это не так подробно и откровенно, как перед Сениным. А затем пытается убедить репортера, который перед тем заверял его в своем намерении «защитить» «старца» от нападок со стороны левых газет, отказаться от публикации материала. Зная после инцидента с «Московскими ведомостями», что угроза для него может исходить и со стороны правых газет, Распутин пытается подыскать понятные для «правого» журналиста аргументы, а заодно выведать его истинные намерения:

«Он остановился, прищурил свои “глазные впадины”, углубился на несколько мгновений вдаль и, неожиданно кинув на меня взгляд, полный недоверия и подозрительности, прибегнув к помощи своих "гипнотизерских" приемов (пристальный взгляд и глажение руки), заговорил болезненно умоляющим голосом:

- Миленький, не надо меня защищать. Лучше, спокойнее для меня было бы, если бы обо мне совсем ничего не писали. Ведь никто, как Бог! Все мы - люди. И грехи наши, ошибки не нам друг у друга взвешивать. Есть и у меня, конечно, ошибочки. Допустил я ошибочек, правда, быть может, немало даже. Но уж не надо было со мной так строго поступать. Отцу Феофану просто следовало быть милостивым. Ведь и сам он не без греха поди. А так человек он хороший. 


\section{Исторические факты, события, феномены}

Вот уж и в ссоре мы с ним, но ничего не могу сказать про него, - вдруг ударился в характеристику Феофана “старец”.

Через продолжительную паузу он сказал:

- Миленький, ты можешь быть со мною откровеннее. Скажи, что еще ты будешь здесь делать. Ведь я знаю: исключительно для меня тебя послали. Ты можешь поделиться со мной. Я никому ничего не скажу. Я знал еще в марте, что ты ко мне приедешь.

- Что именно я к вам приеду? - не без ударения переспросил я “старца”.

- Да-да, о тебе писали из Петербурга.

- Кто же вам писал о моем приезде?

- Да уж там есть, кому писать. Из тайной полиции, - беззастенчиво распространился “святой".

К чувству жалости прибавилось еще чувство гадливости.

Предо мной был просто ловкий мазурик, шарлатан, шарлатан самого низкого калибра, из-за которого не стоило даже прибегать к полицейскому крючкотворству...» [38].

Захваченный чувством гадливости, Жданов не удосуживается предположить, что в данном случае Распутин - так же, как и он сам, - лукавит. В противном случае трудно представить, что знающий о приезде корреспондента левой газеты «старец» почему-то принимает предложенную им игру в беседу с «правым журналистом» и просит «не защищать его».

Как ясно следует из процитированных отрывков, впечатления, которыми Жданов делится по итогам встречи с Распутиным, были в действительности сформированы еще до знакомства со «старцем», и целью встречи было не проверить их, а подтвердить. Не изменило отношения журналиста и то обстоятельство, что Распутин, даже узнав о его обмане, примирительно предложил продолжить общение, вновь пригласив к себе в гости.

Однако, несмотря на то что перед ним, вопреки его ожиданиям, вновь открылся прямой доступ к получению информации из первых рук, Жданов предпочел устроить Распутину еще одну шпионскую западню.

«Но прежде чем являться со вторым и, вероятно, уже последним “визитом” (судя по всему, последний визит не состоялся, т. к. информация о нем в газете так и не появилась. - Д. К., E. C.) к “святому”, я решил предварительно произвести әкскурсию в область заинтересовавшего меня вопроса, какое впечатление от свидания с
Распутиным могут выносить другие случайные и беспристрастные посетители “старца”? Найти ответ на этот интересный вопрос мне быстро представился счастливый случай. Одна интеллигентная девушка, проездом бывшая в Покровском, не отказалась посетить “старца" и затем поделиться со мной своими впечатлениями для печати» [17].

Правда, девушка, имени которой кадетский публицист так и не называет, подошла к выполнению задания по-своему честно, то есть не стала приписывать «старцу» тех черт, которых в нем не обнаружила, но в наличии которых крайне стремился уличить Григория Жданов. В итоге вместо благодарности она удостоилась от газетчика нескольких уничижительных характеристик. Что же касается информации о «старце», которой девушка поделилась со Ждановым, то она была истолкована последним максимально тенденциозно:

«Возвратившись от Распутина в несколько возбужденном, повышенном настроении, девушка заговорила взволнованным голосом:

- Я буквально не понимаю - что за человек этот Распутин?

- Ловкий мазурик, натасканный опытными в создании фиктивной “святости” руководителями, - попробовал я было ответить на вопрос.

Но девушка продолжала:

- Не спорю. Может быть. Но вот меня задачит его индивидуальная черта: несмотря на свою некрасивую, пожилую, даже и безобразную внешность, он, тем не менее, может почему-то располагать к себе.

- Но это только женщин...

- Пусть будет так, - перебила меня, входя в экзальтацию, собеседница. - Не спорю! Но ответить трудно и на это... Первоначально, зайдя в дом к Распутину, я довольно долго не видела самого “старца". Он вышел уже только к чаю, когда я была приглашена за стол. У него какойто странный взгляд...

- Больной, - подсказал я.

- Да-да, это верно, пожалуй, - обрадованно подхватила девушка. - Именно больной... Спросил меня о роде моих занятий, и когда я ответила, сказал: “Доброе сердце везде нужно”. Спросил, почему я одна, почему со мной не пришла моя квартирная хозяйка. (Единственная почти односельчанка Распутина, не посещающая его дом, несмотря на частые приглашения.) - “Я ее очень люблю. Только не подумайте, что я люблю ее плотски, нет! Я люблю ее, как духовную 


\section{Исторический журнал: научные исследования № 4 (28) • 2015}

\section{DOI: $10.7256 / 2222-1972.2015 .4 .17043$}

сестру, духовною любовью”, - поспешил оговориться “старец”. Так между нами завязался разговор, во время которого “старец”, между прочим, все касался меня своими руками, говорил мне на ты, объясняя это привычкой и извиняясь.

“Святой” мазурик, оказывается, из слова в слово повторил и в этот раз, очевидно, уже зазубренный им аргумент в оправдание своей ловеласнической манеры, которая, впрочем, может одновременно считаться и “гипнотизерским" приемом.

- После чаепития, - продолжала моя собеседница, - я была приглашена перейти из столовой в “большую комнату”, “старец”, оставшись со мною тет-а-тет, разоткровенничался сильнее. Показывая мне обстановку своего дома, альбомы с карточками и пр., он одновременно начал много говорить о себе. Затем он еще добавил: "Вот и отец Феофан. Также теперь почему-то против меня, а недавно еще друзьями были. Удивляюсь! Так он человек хороший, и в ссоре я с ним, но ничего не могу дурного сказать про него”.

На мой вопрос, - не держал ли себя "старец” свободно, - девушка несколько смущенно ответила:

- На первый раз он держал себя, несомненно, свободно и даже очень свободно, - не договаривая, очевидно, о чем-то более щекотливом, прервала свою речь моя собеседница.

Этой же девочке “старец” дал “на добрую память” фотографическую карточку с себя с надписью, сделанной собственноручно.

Крупные уродливые буквы:

- "Испытание познание себя и с богом дружба григорий” (это фото появится в номере от 23 июня 1910 г. - Д. К., Е. С.).

Между тем, когда у него просил карточку я, будучи “с визитом”, он почему-то не решился мне дать, предпочитая солгать, что у него вовсе нет с себя карточек...» [39].

Размышляя о том, почему он и его собеседница восприняли Распутина настолько поразному, Жданов делает следующий вывод: «Вообще с мужчинами “святой” держит себя совершенно иначе, значительно сдержаннее, боясь сказать одно лишнее слово» [39]. Данное умозаключение выглядит надуманным, учитывая, что единственным реальным отличием содержания и стилистики общения Григория с самим Ждановым и девушкой явился момент, связанный с дарением фотокарточки. Все остальное - начиная с легких вкрадчивых прикосновений и кончая сетованием на размолвку с Феофаном - в общем, совпадает. Что же касается того, почему Распутин не подарил свое фото Жданову, то это могло быть вызвано тем, что в ходе беседы Григорий заподозрил какой-то подвох: неслучайно он стал просить журналиста не публиковать о нем материал.

Корреспондент «Уральской жизни» Володюша, как Сенин и Жданов, тоже делит свое общение с Распутиным на 2 этапа. Во время первого их разговора на пароходе «старец» не представился, но журналист уже знал, кто он такой.

«Распутин сознательно ускользал от центральной темы - кто он, откуда и зачем ездил. Но у него то и дело вырывались признания вроде: “великий князь такой-то мне говорил”, “графиня такая-то мне советовала”, “у епископа такого-то я видел” и т. д. Он, по-видимому, гордился своими связями и не раз среди разговора намекал на свои посещения Царского Села... Но инкогнито свое сохранял твердо» [36].

Ищущий «желтых» фактов журналист задавал Распутину много вопросов, преимущественно об известных, «скандальных» личностях, о которых также писала «Уральская жизнь»:

«Мне удалось узнать, что едет он теперь из Саратова и Царицына, где виделся с епископом Гермогеном и иеромонахом Илиодором.

Они оба, по мнению старца, “искреннейшие люди” и “воистину религиозные”.

Иного мнения блаженный Распутин об о. Восторгове.

- Речь его - ораторская, и слова в ней ораторские, а не душевные.

Пуришкевичем старец Григорий очарован:

- Замечательной души человек. Глаза ласковые, чудные. Смотришь на него - и не оторвешься...

Зато Дубровин не понравился старцу:

- Угрюмый он, суровый, не светится...

О Союзе русского народа “беспартийный" старец сказал следующее:

- Большая у него заслуга перед Россией. Много пользы принес. Только вот передрались там все... нехорошо это...

По-своему популярные имена и названия, которые звучали в нашем разговоре, стали, между тем, привлекать к нему внимание окружающей публики.

Ловкий “старец”, видимо, тяготился этим вниманием.

Он встал и ушел вниз.

А на дәке уже знали громкое имя моего собеседника. По рукам ходил номер газеты с его портретом и описанием его подвигов. 


\section{Исторические факты, события, феномены}

Два священника, не стесняясь в выражениях, характеризовали подвижническую деятельность веселого “старца”... [36].

Кругом слышался смех, веселые шутки...»

Журналист отмечает, что Распутин в замкнутом пространстве, где все обсуждают его и смеются над ним, чувствует себя крайне неуютно, и не удивляется, что тот снова обращается к нему как к уже знакомому человеку, инстинктивно ища моральной поддержки.

«Когда Распутин снова поднялся наверх, он сразу заметил, что его инкогнито раскрыто. Скрываться далее не имело смысла.

- Вот жизнь... - неопределенно начал он, подсаживаясь ко мне.

- Я вот теперь и умереть могу спокойно. Все испытал, всю жизнь прошел, со всеми людьми жил - от нищей братии до королей... Я есть тот самый Григорий Ефимович Распутин, которого в газетах ругали, - продолжал “старец”. - Может, читали?

Я ответил утвердительно.

- Вот то-то и есть, - говорил “старец”, внимательно ощупывая меня своими странными острыми глазами. - Чего греха таить? Многое из того, что обо мне писали, - правда. Только не поняли меня люди. Я со всеми ласковый, а они это истолковали в другую сторону... А многое правда... И еще в этом, что писали, - зависть виновата. Многие епископы против меня имели. Я вот теперь был в Москве у Тихомирова, редактора "Московских ведомостей". Говорит - все разоблачение от епископов идет. Ну, Столыпин вызвал его и запретил обо мне печатать... Больше не будут!

- Аскажите, Григорий Ефимович, вмешался в наш разговор священник-миссионер с маленьким симпатичным лицом, одетый в старенькую поношенную рясу. - А скажите, в чем ваша идея состоит, что вы, помимо церкви, проповедуете?

“Старец" затруднился ответить на прямо поставленный вопрос.

- Моя идея к тому ведет, чтобы люди ласковыми друг с другом жили. И все - святость. Кто на жизнь обижен - иди к брату своему или сестре и найди ласку...

Он, по-видимому, имел очень смутное представление о своей “идее” и о своем призвании.

Судя по его разговору, трудно предположить, чтобы он считал своим призванием “возрождение института старцев”, как об этом сообщалось в газетах» [36].
Володюша был явно разочарован обрывочными рассуждениями Распутина, выдержанными в гуманистическом духе, весь смысл которых, по сути, сводился к тому, что люди должны быть отзывчивее и добрее друг к другу. Эти человечные слова не соответствовали тем громким разоблачениям «зверя», которые публиковали левые газеты. Поэтому свою публикацию Володюша закончил вялой попыткой расцветить свое повествование бульварным морализаторством:

«Он производил впечатление недалекого, но хитрого мужичка, сообразившего, что он может прекрасно использовать свою “простоту", а попутно и простоту доверчивых и религиозных людей.

Речь его лилась елейно, с нарочитой искренностью в интонациях, между тем как глаза его с пристальностью опытного развратника ощупывали сидевших на дэке женщин...

Положительно, у меня пропадал к нему интерес...»[36].

Таким образом, к лету 1910 г. распутинский дискурс претерпел жанровую диверсификацию, распавшись на аналитическое, оппозиционное и «желтое» направления. Следует подчеркнуть, что этот процесс (как и само исходное становление распутинской темы) произошел на страницах региональной, а не столичной прессы.

Содержательные и стилистические различия трех упомянутых подходов были весьма существенными.

Аналитическому направлению был присущ интерес к Григорию Распутину как к личности, а также профессиональный журналистский подход к фактам, которые не публиковались без ссылок на источник и строго отделялись от комментария.

Данный подход позволил А. Сенину сделать наиболее правдоподобные и внутренне непротиворечивые выводы: ничего демонически сверхъестественного, равно как и зловеще криминального, в этом человеке нет, поэтому причины его возвышения тоже должны быть «земными» и рационально объяснимыми. Сенин остановился на версии о том, что Распутин - инструмент в руках тех, кто пытается через него оказывать влияние на царскую чету:

«Чем и кому может быть полезен этот грубый челдон? Какую роль играет он в тех сферах, где принят и вращается как свой человек? Где и как он находит приложение своей “любви”? У него громадный круг знакомых всюду и везде: и в столицах, и в Одессе, и в Екатеринославе... 


\section{Исторический журнал: научные исследования № 4 (28) • 2015}

\section{DOI: $10.7256 / 2222-1972.2015 .4 .17043$}

Года полтора прошло с тех пор, как в последний раз я видел Григория Ефимовича. Волна событий высоко вынесла его на мутную поверхность русской жизни, о Григории Распутине-Новом говорит теперь вся печать, все слои русской читающей публики от верху до низу. И, знакомясь с делами, разоблачениями и припоминая все, что он лично рассказывал, мне сдается, что Распутин - лишь ловкое орудие в чьих-то сильных руках, которое направлялось на преследование известных целей, на влияние на тех, от кого зависят судьбы русского народа» [29].

Также для А. Сенина было характерно этически корректное общение с Распутиным.

В отличие от А. Сенина, оппозиционно настроенный К. Жданов изначально обозначал свое резко негативное и уничижительное отношение к «старцу», заявив о его близости к царской семье. Целью оппозиционных публикаций, посвященных личности «старца», оказывалась максимальная дискредитация его, а через него и всего правящего режима. Выводы таких статей оказывались такими же, как и их изначальные посылы: «И действительно, как много грязного, порочного и преступного в жизни “старца" Распутина, этого “святого Вытула”, и, пожалуй, здесь уже не о церковном суде над ним нужно вести речь, а о его уголовной ответственности» [27].

В этом случае имя Распутина выступало как своего рода политический эвфемизм, призванный заменить собой имена тех, кого либеральная пресса не могла публично призвать к ответу.

Наконец, «желтый» журналистский подход, в частности, характерный для корреспондента «Уральской жизни», имел целью просто «нагнетание страстей». Ни о какой целостности и глубине описания и анализа фактуры здесь говорить не приходилось. Все сводилось к тревожно-риторическим восклицаниям с эротической начинкой:

«Но чем же, чем объяснить его (Распутина. Д. К., E. C.) влияние на людей разного возраста и положения? - думал я. - Чем привлекал этот грязный полуграмотный мужичонка сердца и души женщин, среди которых было много красивых, умных и развитых? Было ли это влияние гипнотической силы, которой он владеет? Или это другой гипноз - самогипноз религиозной экзальтации, который ослеплял и порабощал? И если верно, что каждое время имеет таких святых, каких оно стоит, то что за ужасное время мы переживаем? Проходимец и половой психо- пат в качестве пророка религиозного возрождения в политических и великосветских салонах! Что за фантастическое время!» [36].

Особо следует подчеркнуть, что представители оппозиционного и «желтого» направлений при освещении распутинской темы действовали с нарушением как профессиональных журналистских, так и общих этических принципов. Оппозиционер К. Жданов позволял себе массу голословных либо не подкрепленных ссылкой на источники негативных оценок и «свидетельств», а также прямых домыслов. Помимо этого, он явно стилистически обрабатывал (если не домысливал) реплики әкспертов «из народа». Также в качестве «профессионального метода работы» Жданов использовал обман интервьюируемого. «Бульварный» журналист Володюша (В. Швейцер), помимо домыслов и не подтвержденных источниками фактов, делал акцент на гипнотических и эротических сторонах образа «полового психопата» Распутина, а также использовал собственные тенденциозные (не вытекающие из приведенных фактов) оценки и риторическое «сгущения красок».

Оппозиционное и «желтое» направления объединяло стремление преподнести феномен «старца»в контексте критики политических и социальных «верхов». Володюша упоминал о связях «старца» с великими князьями, графами, епископами, политическими лидерами и газетными редакторами, а также о протекции, которую ему оказал лично премьер-министр. К. Жданов первым среди российских журналистов упомянул в связи с личностью Григория Распутина имя его главного покровителя Николая II.

Именно эти два направления - оппозиционное и жёлтое - получат в дальнейшем в освещении распутинской темы наибольшие развитие и резонанс.

Несмотря на то что для оппозиционной и «желтой» прессы распутинская сенсация представляла различную ценность (в первом случае была эффективным оружием в информационной борьбе с правительством, во втором - оказывалась полезным средством повышения популярности издания), газетам того и другого типа публикации, посвященные «старцу», приносили конкретную коммерческую выгоду. Эти материалы пользовались неизменным читательским спросом, активно перепечатывались другими периодическими изданиями и, таким образом, 


\section{Исторические факты, события, феномены}

работали на повышение популярности, а следовательно, и коммерческой успешности газет, публиковавших на своих страницах распутинский «эксклюзив». Данный аспект также необходимо

\section{Библиография:}

1. Беспалова А. Г., Корнилов Е. А., Короченский А. П., Лучинский Ю. В., Станько А. И. История мировой журналистики. М.; Ростов-на-Дону: Издательский центр «МарТ», 2003. 432 с.

2. Раздача подарков на монастырском подворье // Царицынский вестник. 1909. 2 декабря.

3. Проводы иеромонаха Илиодора // Царицынский вестник. 1909. 3 декабря.

4. ‥‥ Блаженный старец Григорий // Русское слово. 1910. 8 января.

5. Старец Григорий // Царицынский вестник. 1910.13 января.

6. Новоселов М. Духовный гастролер Григорий Распутин // Московские ведомости. 1910. 2 марта.

7. Скептик. Размышления // Речь. 1910. 2 мая.

8. С. В. Распутин-Новых // Речь. 1910. 20 мая.

9. «Старец» Григорий // Биржевые ведомости (второе издание). 1910. 21 мая.

10. Новоселов М. Еще нечто о Григории Распутине // Московские ведомости. 1910. 30 марта.

11. О Григории Распутине, иеромонахе Илиодоре и прочих // Московские ведомости. 1910. 30 апреля.

12. Еще о Григории Распутине // Царицынский вестник. 1910. 4 мая.

13. Старец Григорий // Царицынский вестник. 1910.11 мая.

14. Восторгов, прот. Григорий Распутин и иером. Илиодор // Царицынская мысль. 1910. 20 мая.

15. Арест старца Григория Распутина // Царицынский вестник. 1910. 29 мая.

16. 12 «сестер» Григория Распутина // Утро России. 1910. 30 мая.

17. Сенин А. Григорий Распутин // Южная заря. 1910. 30 мая.

18. Распутин-Новых // Уральский край. 1910. 1 июня [Перепечатка статьи: С. В. Распутин-Новых // Речь. 1910. 26 мая].

19. Распутин-Новых. «Подвижник» села Покровского Тюменского уезда // Уральский край. 1910. 2 июня [Перепечатка статьи: С. В. Распутин-Новых // Речь. 1910. 28 мая].

20. Распутин-Новых. «Подвижник» села Покровского Тюменского уезда // Уральский край. 1910. 4 июня [Перепечатка статьи: С. В. Распутин-Новых // Речь. 1910. 30 мая].

21. Распутин-Новых. «Подвижник» села Покровского Тюменского уезда // Уральский край. 1910. 12 июня [Перепечатка статьи: С. В. Распутин-Новых // Речь. 1910.7 июня].

22. Старец Григорий // Уральская жизнь. 1910. 1 июня [Перепечатка статьи: С. В. Распутин-Новых // Речь. 1910. 26 мая].

23. Старец Григорий // Уральская жизнь. 1910. 2 июня [Перепечатка статьи: С. В. Распутин-Новых // Речь. 1910. 28 мая].

24. Старец Григорий // Уральская жизнь. 1910. 4 июня [Перепечатка статьи: С. В. Распутин-Новых // Речь. 1910. 30 мая].

25. Пухов Д. Ю. К истории дореволюционной екатеринбургской печати: газета «Голос Урала» // Урало-Сибирская научнопрактическая конференция // [Электронный ресурс]

URL:http://www3.uran.ru/reports/usspe_c_2003/thesesofreports/t46.htm (дата обращения: 2.11.2015).

26. Жданов К. В гости к «старцу» Распутину // Уральский край. 1910. 11 июня.

27. Жданов К. В гости к «старцу» Распутину // Уральский край. 1910. 22 июня.

28. Масанов И. Ф. Словарь псевдонимов русских писателей, ученых и общественных деятелей. В 4 томах. Т. 1. М.: Издательство Всесоюзной книжной палаты, 1956. 442 с.

29. Сенин А. Григорий Распутин // Южная заря. 1910. 4 июня.

30. Жданов К. В гости к «старцу» Распутину // Уральский край. 1910. 15 июня.

31. Жданов К. В гости к «старцу» Распутину // Уральский край. 1910. 16 июня.

32. Герасимов А. В. На лезвии с террористами // «Охранка». Воспоминания руководителей политического сыска. Т. 2. М.: Новое литературное обозрение, 2004. С. 141-342.

33. Жданов К. В гости к «старцу» Распутину // Уральский край. 1910. 17 июня.

34. Программа Конституционно-демократической партии [1905г.] // Программы политических партий России. М.: РОССПЭН, 1995. С. 325-336.

35. Жданов К. В гости к «старцу» Распутину // Уральский край. 1910. 24 июня.

36. Володюша. Встреча со «старцем» Григорием // Уральская жизнь. 1910. 12 июня.

37. Сенин А. Григорий Распутин // Южная заря. 1910. 2 июня.

38. Жданов К. В гости к «старцу» Распутину // Уральский край. 1910. 18 июня.

39. Жданов К. В гости к «старцу» Распутину // Уральский край. 1910. 19 июня.

40. Чернышев А. В. О возрасте Григория Распутина и других биографических деталях // Отечественные архивы. 1992. № 1. С. 112-114.

41. Коцюбинский А. П., Коцюбинский Д. А. Григорий Распутин: тайный и явный. Житие опытного старца сквозь призму его личности. СПб.; М.: Лимбус Пресс, 2003. 480 с.

42. Мясищев В. Н. Психоневроз и псевдоневроз // Личность и неврозы. Л.: Издательство Ленинградского университета, 1960. С. $262-281$. 


\section{Исторический журнал: научные исследования № 4 (28) • 2015}

DOI: $10.7256 / 2222-1972.2015 .4 .17043$

References (transliterated):

1. Bespalova A. G., Kornilov E. A., Korochenskii A. P., Luchinskii Yu. V., Stan'ko A. I. Istoriya mirovoi zhurnalistiki. M.; Rostov-naDonu: Izdatel'skii tsentr «MarT», 2003. $432 \mathrm{~s}$.

2. Razdacha podarkov na monastyrskom podvor'e // Tsaritsynskii vestnik. 1909. 2 dekabrya.

3. Provody ieromonakha Iliodora // Tsaritsynskii vestnik. 1909. 3 dekabrya.

4. N. N. Blazhennyi starets Grigorii // Russkoe slovo. 1910. 8 yanvarya.

5. Starets Grigorii // Tsaritsynskii vestnik. 1910. 13 yanvarya.

6. Novoselov M. Dukhovnyi gastroler Grigorii Rasputin // Moskovskie vedomosti. 1910. 2 marta.

7. Skeptik. Razmyshleniya // Rech'. 1910. 2 maya.

8. S. V. Rasputin-Novykh // Rech'. 1910. 20 maya.

9. «Starets» Grigorii // Birzhevye vedomosti (vtoroe izdanie). 1910. 21 maya.

10. Novoselov M. Eshche nechto o Grigorii Rasputine // Moskovskie vedomosti. 1910. 30 marta.

11. O Grigorii Rasputine, ieromonakhe Iliodore i prochikh // Moskovskie vedomosti. 1910. 30 aprelya.

12. Eshche o Grigorii Rasputine // Tsaritsynskii vestnik. 1910. 4 maya.

13. Starets Grigorii // Tsaritsynskii vestnik. 1910.11 maya.

14. Vostorgov, prot. Grigorii Rasputin i ierom. Iliodor // Tsaritsynskaya mysl'. 1910. 20 maya.

15. Arest startsa Grigoriya Rasputina // Tsaritsynskii vestnik. 1910. 29 maya.

16. 12 «sester» Grigoriya Rasputina // Utro Rossii. 1910. 30 maya.

17. Senin A. Grigorii Rasputin // Yuzhnaya zarya. 1910. 30 maya.

18. Rasputin-Novykh // Ural'skii krai. 1910. 1 iyunya [Perepechatka stat'i: S. V. Rasputin-Novykh // Rech'. 1910. 26 maya].

19. Rasputin-Novykh. «Podvizhnik» sela Pokrovskogo Tyumenskogo uezda // Ural'skii krai. 1910. 2 iyunya [Perepechatka stat'i: S. V. Rasputin-Novykh // Rech'. 1910. 28 maya].

20. Rasputin-Novykh. «Podvizhnik» sela Pokrovskogo Tyumenskogo uezda // Ural'skii krai. 1910. 4 iyunya [Perepechatka stat'i: S. V. Rasputin-Novykh // Rech'. 1910. 30 maya].

21. Rasputin-Novykh. «Podvizhnik» sela Pokrovskogo Tyumenskogo uezda // Ural'skii krai. 1910. 12 iyunya [Perepechatka stat'i: S. V. Rasputin-Novykh // Rech'. 1910.7 iyunya].

22. Starets Grigorii // Ural'skaya zhizn'. 1910. 1 iyunya [Perepechatka stat'i: S. V. Rasputin-Novykh // Rech'. 1910. 26 maya].

23. Starets Grigorii // Ural'skaya zhizn'. 1910. 2 iyunya [Perepechatka stat'i: S. V. Rasputin-Novykh // Rech'. 1910. 28 maya].

24. Starets Grigorii // Ural'skaya zhizn'. 1910. 4 iyunya [Perepechatka stat'i: S. V. Rasputin-Novykh // Rech'. 1910. 30 maya].

25. Pukhov D. Yu. K istorii dorevolyutsionnoi ekaterinburgskoi pechati: gazeta «Golos Urala» // Uralo-Sibirskaya nauchnoprakticheskaya konferentsiya // [Elektronnyi resurs]

URL:http://www3.uran.ru/reports/usspe_c_2003/thesesofreports/t46.htm (data obrashcheniya: 2.11.2015).

26. Zhdanov K. V gosti k «startsu» Rasputinu // Ural'skii krai. 1910.11 iyunya.

27. Zhdanov K. V gosti k «startsu» Rasputinu // Ural'skii krai. 1910. 22 iyunya.

28. Masanov I. F. Slovar' psevdonimov russkikh pisatelei, uchenykh i obshchestvennykh deyatelei. V 4 tomakh. T. 1. M.: Izdatel'stvo Vsesoyuznoi knizhnoi palaty, 1956.442 s.

29. Senin A. Grigorii Rasputin // Yuzhnaya zarya. 1910. 4 iyunya.

30. Zhdanov K. V gosti k «startsu» Rasputinu // Ural'skii krai. 1910. 15 iyunya.

31. Zhdanov K. V gosti k «startsu» Rasputinu // Ural'skii krai. 1910.16 iyunya.

32. Gerasimov A. V. Na lezvii s terroristami // «Okhranka». Vospominaniya rukovoditelei politicheskogo syska. T. 2. M.: Novoe literaturnoe obozrenie, 2004. S. 141-342.

33. Zhdanov K. V gosti k «startsu» Rasputinu // Ural'skii krai. 1910.17 iyunya.

34. Programma Konstitutsionno-demokraticheskoi partii [1905 g.] // Programmy politicheskikh partii Rossii. M.: ROSSPEN, 1995. S. 325-336.

35. Zhdanov K. V gosti k «startsu» Rasputinu // Ural'skii krai. 1910. 24 iyunya.

36. Volodyusha. Vstrecha so «startsem» Grigoriem // Ural'skaya zhizn'. 1910.12 iyunya.

37. Senin A. Grigorii Rasputin // Yuzhnaya zarya. 1910. 2 iyunya.

38. Zhdanov K. V gosti k «startsu» Rasputinu // Ural'skii krai. 1910.18 iyunya.

39. Zhdanov K. V gosti k «startsu» Rasputinu // Ural'skii krai. 1910. 19 iyunya.

40. Chernyshev A. V. O vozraste Grigoriya Rasputina i drugikh biograficheskikh detalyakh // Otechestvennye arkhivy. 1992 . № 1. S. 112-114.

41. Kotsyubinskii A. P., Kotsyubinskii D. A. Grigorii Rasputin: tainyi i yavnyi. Zhitie opytnogo startsa skvoz' prizmu ego lichnosti. SPb.; M.: Limbus Press, 2003. 480 s.

42. Myasishchev V. N. Psikhonevroz i psevdonevroz // Lichnost' i nevrozy. L.: Izdatel'stvo Leningradskogo universiteta, 1960. S. $262-281$. 